\title{
The earthquake sedimentary record in the western part of the Sea of Marmara, Turkey
}

\author{
L. Drab ${ }^{1}$, A. Hubert Ferrari ${ }^{2}$, S. Schmidt ${ }^{3}$, and P. Martinez ${ }^{3}$ \\ ${ }^{1}$ CNRS/INSU, UMR8538, Laboratoire de Géologie de l'Ecole Normale Supérieure, Paris, France \\ ${ }^{2}$ Université de Liège, batiment de géographie physique, Département de Géographie, Université de Liège Allée du 6 août, 2 , \\ Bât. B11, Sart Tilman 4000, Liège, Belgique \\ ${ }^{3}$ UMR 5805 EPOC, OASU, Site de Talence, Université Bordeaux 1, Avenue des Facultés 33405, Talence Cedex, France \\ Correspondence to: L. Drab (drab@geologie.ens.fr)
}

Received: 14 September 2011 - Revised: 3 March 2012 - Accepted: 18 March 2012 - Published: 27 April 2012

\begin{abstract}
The submarine part of the North Anatolian Fault (NAF) is a very significant hazard for the 12 million people living in Istanbul (Turkey). An accurate seismic risk assessment necessitates paleoseismological data, which can be retrieved in the Marmara Sea by using sedimentary cores. Here, a record of turbidites was obtained in five cores, spanning the Tekirdağ Basin, the Western High and the Central Basin linked by the Tekirdağ fault segment. The turbidites are synchronous at different sites across the two basins and through the structural high pointing to shaking by earthquakes as a triggering mechanism. In particular, the $M=7.4$ 1912 Mürefte earthquake left a distinctive sedimentary imprint in all the studied cores. Radiocarbon dating implies a turbidite recurrence interval of about $300 \mathrm{yr}$. The low number of seismo-turbidites documented in the Central Basin compared to the Tekirdağ Basin suggests quasi-synchronous ruptures of the Tekirdağ Segment and the adjacent Central Segment of the NAF or a partial seismic slip on the Central Segment. Both scenarios have implications regarding seismic hazard. Finally, though we obtained a paleoseismological record of the ruptures along the Tekirdağ Segment, further chronological constraints are needed to better date the events and to confirm the completeness of the obtained record.
\end{abstract}

\section{Introduction}

Hazard risk assessment for populations living in tectonically active areas can be improved using paleoseismology, by building an extended database of major earthquakes and earthquake recurrence time (Fraser et al., 2010). Even though most studies in this field of inquiry were historically based on on-land field work, e.g. in California, in Turkey, in Italy, in Himalayas, in Tibet (Dolan et al., 2003; Weldon et al., 2004; Galli et al., 2008; Kondo et al., 2008; Fraser et al., 2010; Klinger et al., 2011), recently interesting offshore studies have appeared (Goldfinger et al., 2003a; Goldfinger, 2011). These studies use the identification of mass-wasting deposits triggered by large earthquakes to obtain records of events over 1000s of years (McHugh et al., 2006; Beck et al., 2007). Mass-wasting deposits related to earthquakes have a specific signature and can be distinguished from other deposits emplaced by hyperpycnal flow, wave storm loading, among others (Gorsline et al., 2000; Nakajima and Kanai, 2000; Shiki et al., 2000; Beck et al., 2007). Earthquake-triggered turbidites may mobilise 5 to 10 times the sediment volume of classical turbidites (Gorsline et al., 2000) and usually show liquefaction or flaser bedding structures (Beck et al., 2007). Their granulometric signature reflects a high energy transportation mechanism, forming a mass flow and a very large suspension cloud (Shiki et al., 2000). As a result seismoturbidites have a sharp and wavy erosional base (Shiki et al., 2000), and can be divided into a basal sand sublayer and a thick silt sublayer, characterized by a poor size grading and coeval deposition of sand, silt and clay particles (Nakajima and Kanai, 2000; Shiki et al., 2000).

In this paper, we study the turbiditic sedimentation in the Marmara Sea, which is crossed by the North Anatolian Fault, a major active strike-slip fault, causing the rupture of $M \geq 7$ earthquakes. The presence of the urban area of Istanbul on its shoulder, where about 12 million people live, makes this region a major spot for seismic hazard studies. We identified 
turbiditic deposits in five 3 to $4 \mathrm{~m}$-long cores, which sample its different basins and highs. We then use global sedimentological changes to correlate the different cores and to characterize the general depositional pattern in the Marmara Sea. Radiogenic lead data allow us to discriminate the turbidites triggered by the 1912 earthquake. The granulometric characteristics of the other turbidites, their lateral extent and the synchronicity of proximal and distal deposits are used to infer a seismic trigger. Finally, we discuss the paleoseismological implication of the identified seismo-turbidites.

\section{Settings}

\subsection{Tectonic setting}

The North Anatolian Fault (NAF) is a 1500 km-long dextral strike slip fault, accommodating the westward extrusion of the Anatolian Plate (Barka and Kadinsky-Cade, 1988; Sengör et al., 2005). In the Marmara Sea area, the NAF separates into branches, spreading out the deformation over a width of $130 \mathrm{~km}$ (Barka and Kadinsky-Cade, 1988). The northern branch of the NAF accommodates most of the deformation (McClusky et al., 2003) and runs across the 170 km-long Marmara Sea.

The Marmara Sea is composed of three-aligned marine pull apart basins, reaching a maximum water depth of 1250 m (Le Pichon et al., 2001; Armijo et al., 2002; Sar1 and Çağatay, 2006). From west to east the basins are called Tekirdağ, Central and Çınarcık. They are respectively associated with the present active Tekirdağ, Central and Çınarcık fault segments (Fig. 1). The different faults segments and the related basins have been imaged by seismic reflection and refraction profiles (Seeber et al., 2006; Carton et al., 2007; Bécel et al., 2009) and modelled (Hubert-Ferrari et al., 2000; Muller and Aydin, 2005). The basins are separated by two topographic ridges: the Western High and Central High, with a respective water depth of $700 \mathrm{~m}$ and $900 \mathrm{~m}$ (Le Pichon et al., 2001; Armijo et al., 2005). The basins are sensitive to masswasting events triggered by major earthquakes, rupturing the fault strand, which crosses them (McHugh et al., 2006; Sar1 and Çağatay, 2006; Beck et al., 2007).

\subsection{The historical earthquake record}

The northern branch of the NAF in the Marmara Sea is a major active fault characterized by a GPS-based right-lateral slip rate about $20 \mathrm{~mm} \mathrm{yr}^{-1}$ (McClusky et al., 2003). The resulting accumulated stresses are episodically released by major and destructive earthquakes recorded in history over $2000 \mathrm{yr}$ (Ambraseys, 2002). During the 20th century, the $1912 M=7.4$ Mürefte earthquake ruptured the Ganos Segment, located west of the Marmara Sea and probably also the offshore part of the Tekirdağ Segment (Armijo et al., 2005; Aksoy et al., 2010). In 1999, the $M=7.4$ Izmit earthquake took place just east of the Marmara Sea (Hubert-Ferrari et al.,
2000). Five other events with $M>7$ occurred during the period from 1509 to 1900 (1719, 1754, 1766 May, $1766 \mathrm{Au}-$ gust, 1894) (Fig. 1, Ambraseys 2002; Pondard et al. 2007). The historical record provides earthquake damage data restricted to the on-land borders of the Marmara Sea and cannot be used alone to determine the epicenters and surface ruptures. Even recent earthquake databases do not provide routinely accurate earthquake epicenters and foci locations (Örgülü, 2011). Finally, submarine scarps associated with past recent ruptures in 1912 and possibly in 1894 complement the seismological data set (Armijo et al., 2005; Pondard, 2006).

\subsection{Previous sedimentological core studies in the Marmara Sea}

The Marmara Sea connects the Black Sea to the Aegean Sea through the Bosphorus and Dardanelles Straits. Because of its particular geographic situation, it is highly sensitive to climatic and environmental changes and was the focus of multiple sedimentological investigations (Çağatay et al., 2000; Abrajano et al., 2002; Hiscott et al., 2002; Major et al., 2002; Mudie et al., 2002; Vidal et al., 2010). A key issue for these studies is the understanding of the nature of the reconnection between the Black Sea and the Mediterranean Sea (catastrophic Major et al. 2002; or progressive Çağatay et al. 2000; Hiscott et al. 2002) 9 kyr BP ago (Çağatay et al., 2000; Vidal et al., 2010).

Recent environmental changes related to anthropogenic disturbances were also identified. In particular, pollen studies (Mudie et al., 2002) put forward the occurrence of a progressive deforestation starting $4 \mathrm{kyr}$ ago in the watershed surrounding the Marmara Sea. During the Beyşehir Occupation Phase (ca. 1300 yr BC to ca. AD 200-800 yr; Eastwood et al. 1998), vegetation changes and land degradation have been documented in the Lakes Manyas and Uluabat (Kazanci et al., 2004). In both lakes, which are part of the Kocasu River, a major source of sediments for the Marmara Sea, with higher rates of sedimentation started around $2 \mathrm{kyr} B$. In parallel, a progressive increase in sedimentation rate on the southern Marmara shelf occurred (Kazanci et al., 2004) at the same time as the formation of the most recent sapropel, 4750-3500 14C yr BP ago (Çağatay et al., 2000). Eris et al. (2007) also suggested that the growth of the prodelta at the entrance of the Bosphorus was related to an increase in sediment supply triggered by the clearing of forests in watersheds.

In addition to paleoclimatic investigations, paleoseismology studies have recently used turbidites for deciphering the earthquake history (McHugh et al., 2006; Sarı and Çağatay, 2006; Beck et al., 2007). Multi-proxy analyses were performed on cores coming from Central Basin (McHugh et al., 2006; Beck et al., 2007) and Tekirdağ Basin (McHugh et al., 2006). Both authors conclude that (1) significant turbiditic deposition directly related to earthquake shaking occurs in 


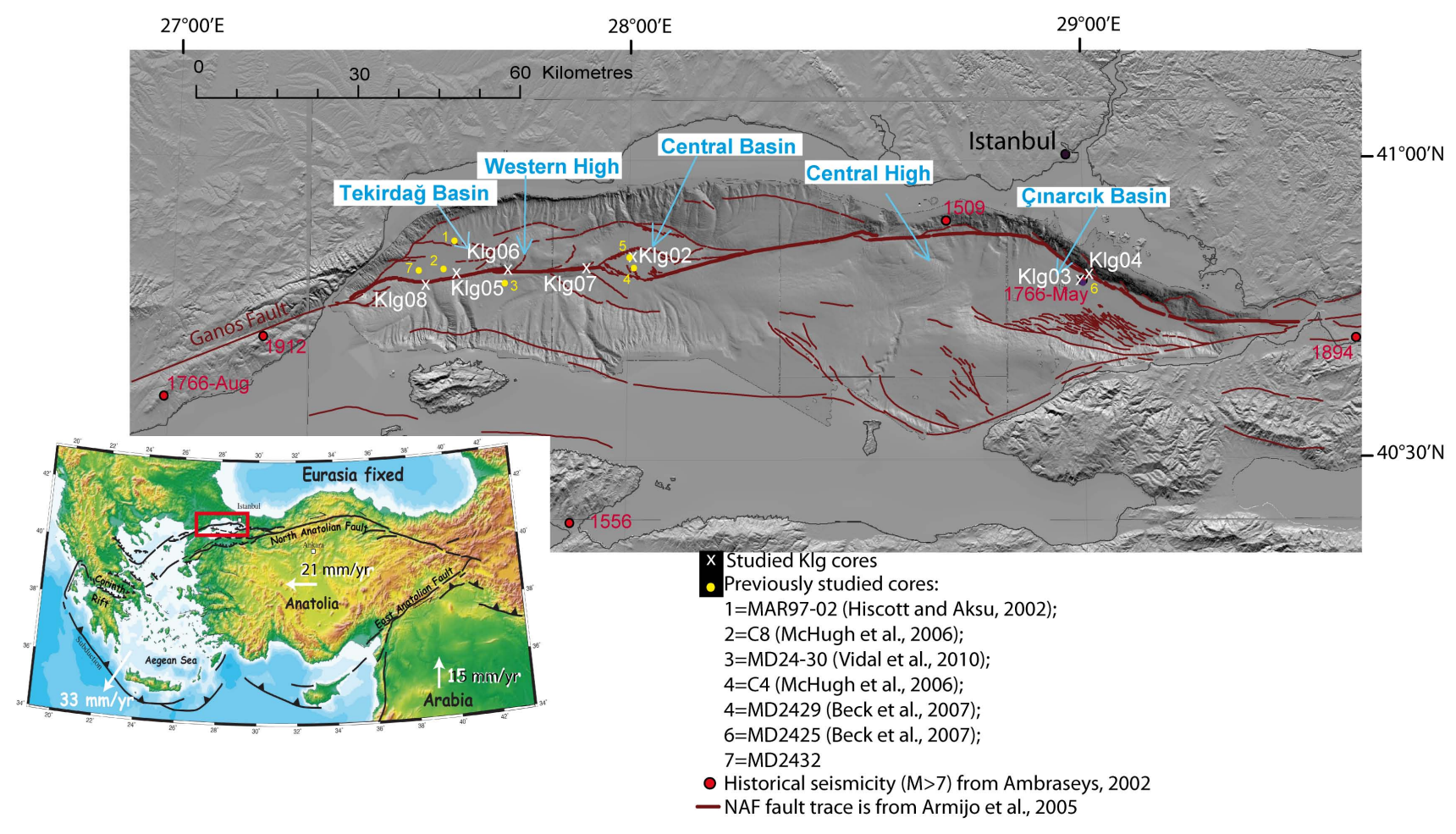

Fig. 1. General context of the Marmara Sea, crossed by the North Anatolian Fault (NAF). Main structures are labelled in blue. Global tectonic context of the Anatolian Plate is included as inset with GPS velocities from Reilinger et al. (2006), with a red box indicating the location of Fig. 1.

the Marmara Basin (McHugh et al., 2006; Beck et al., 2007), (2) basins' filling is mainly controlled by active faults (Uçarkuş, 2010) and may document earthquake rupture along the associated fault segments (McHugh et al., 2006; Beck et al., 2007), and (3) seismoturbidites are associated with oscillating bottom currents (seiche), with variable suspended load or bedload (Beck et al., 2007).

\section{Material}

The cores studied ( $\mathrm{Klg} 02$ to $\mathrm{Klg} 08)$ were collected in the Marmara Sea during the Marmascarps mission in 2002, shortly after the $1999 M=7.4$ Izmit earthquake (Armijo et al., 2005). The coring sites are similar to locations of ROV short cores (Uçarkuş, 2010) and long cores studied in Beck et al. (2007), Londeix et al. (2009), Vidal et al. (2010). The seven Kullenberg cores are $3.5 \mathrm{~m}$ to $4.5 \mathrm{~m}$ long (Table 1 ) and are distributed in specific areas along the fault (Fig. 1). They provide a link between very short interface cores (ROV) and the very long cores of the Marion Dufresne cruise, in which upper meters are often missing or strongly disturbed.

The $\mathrm{Klg} 05$ and $\mathrm{Klg} 08$ cores are situated $6 \mathrm{~km}$ apart in the southern part of the Tekirdağ Basin, along the Tekirdağ Segment of the NAF, at the outlet of deep canyons (Fig. 1). Fur- ther east, the $\mathrm{Klg} 06$ core samples the intersection between the Western High and the Tekirdağ Basin, and the Klg07 core samples the intersection between the Central Basin and the Western High. These two cores, lying $15 \mathrm{~km}$ apart, are close to the Tekirdağ Segment. Klg02 is located in the inner part of the Central Basin pull apart (Armijo et al., 1999), between the Tekirdağ and the Central Segments of the NAF. Klg03 and Klg04 sample the Çınarcık Basin. The paper focuses on the $\mathrm{Klg} 02$, Klg05, Klg06, Klg07 and Klg08 cores, but the XRF-data obtained for the Klg04 core are presented here, because it highlights global sedimentary changes occurring across the whole Marmara Sea.

\section{Methods}

\subsection{Core processing, imaging and physical properties}

The sedimentary facies observed in cores were described first to provide a basic core log. The visual core description was based on colour, bedding, sedimentary structures and disturbances, grain size distribution, texture, bioturbation and fossil content. This description was refined by using $\mathrm{X}$-ray radiograms, granulometric data, magnetic susceptibility measurements and XRF-scanning data. 


\section{$A: K \lg 05-250 \mathrm{~cm}$}

$\%$ sand; \%clay

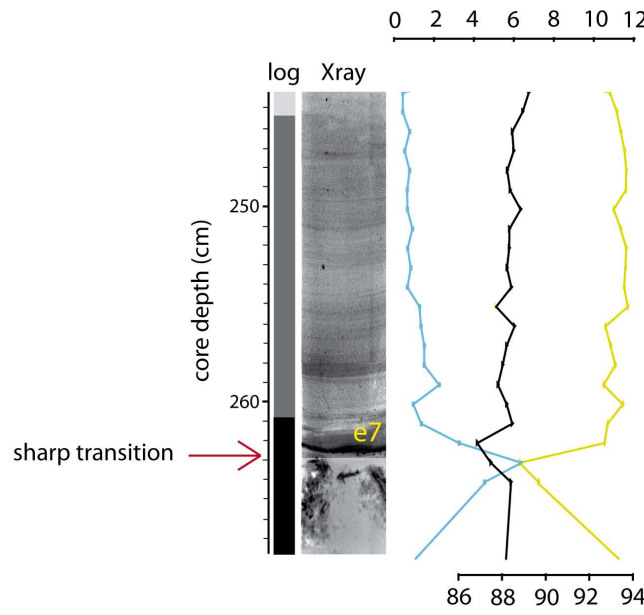

$B$ : KIg05 - 20 cm

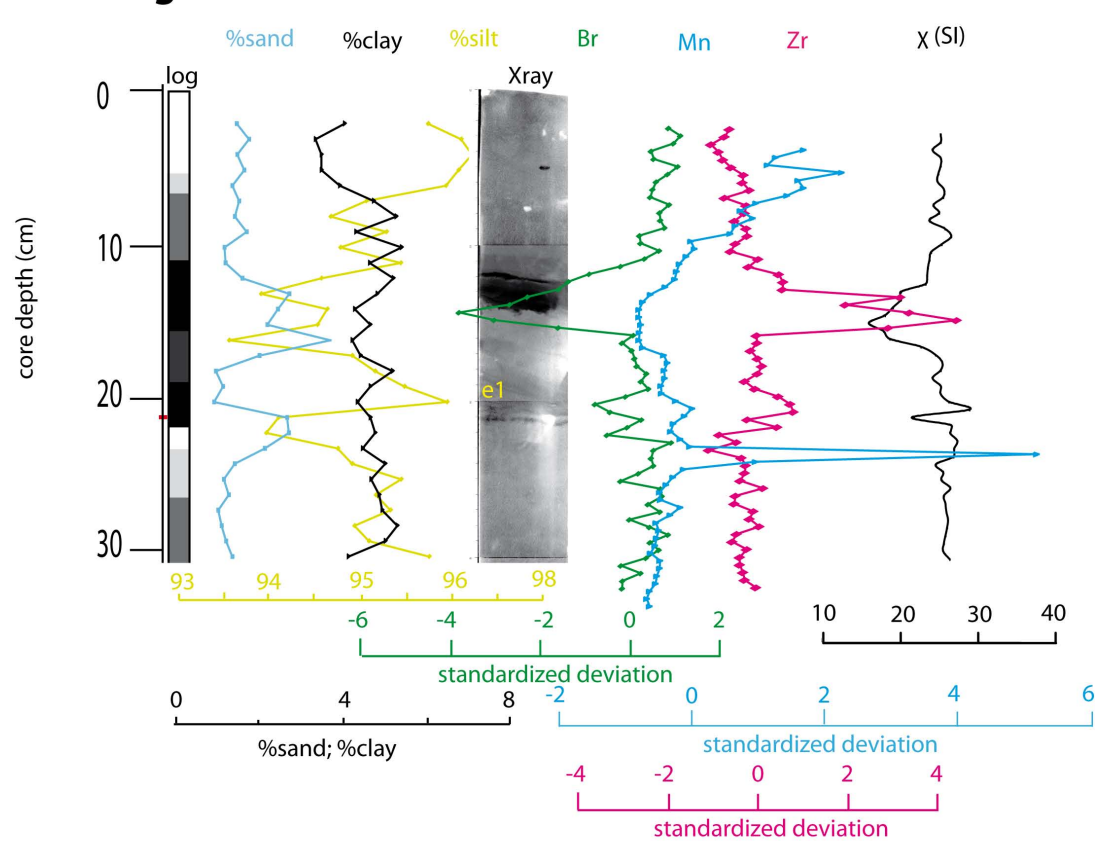

Fig. 2. Typical examples of turbidites: granulometric and geochemical signatures as described in Sect. 5. Turbidites are composed of a basal sandy sublayer, an upper silty sublayer with frequent laminations and a top light grey clayey sublayer. A: X-ray imagery and granulometry zooms of event 7 in Klg05. Yellow label on the X-ray indicates the position of the event as in Fig. 4. B: X-ray imagery, granulometry and geochemical profiles of event 1 in Klg05. Turbidites can have a positive signature in Zirconium (pink curve), negative in bromine (green curve). Manganese (blue curve) typically shows a peak just below turbidites. Yellow names indicate events as referenced in Fig. 4.

In the X-ray pictures (EPOC scopix system in Bordeaux 1 University), the grey scale is proportional to the $\mathrm{X}$ ray penetration into the core and to the sediment density, with sand being usually black and clay light grey (Migeon et al., 1999). The X-ray imagery was particularly useful to identify all possible sedimentary structures, like lami- nated coarser episodes, low angle symmetric cross lamination, ball-and-pillow structures, water-escape structures, displacements previously interpreted in sedimentary cores sampling the Tekirdağ Basin, as specific imprints of major earthquakes by Beck et al. (2007). 


\section{a: Turbidite e6-KIg05}
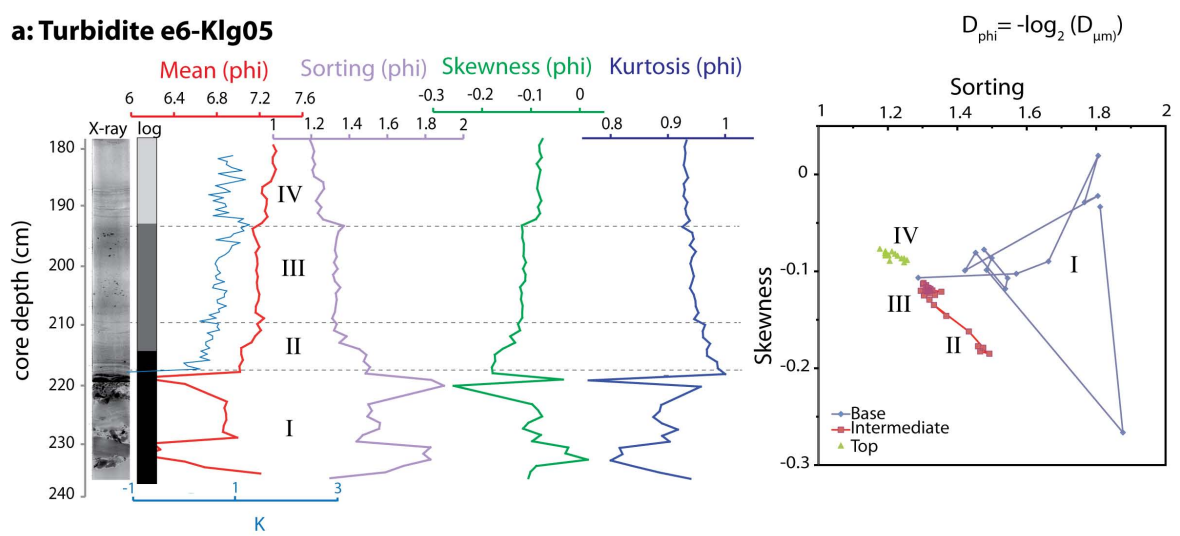

b: Turbidite e4-KIg02

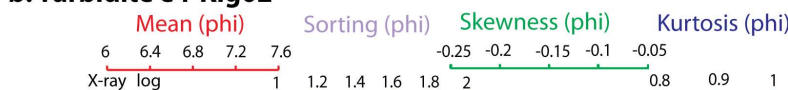

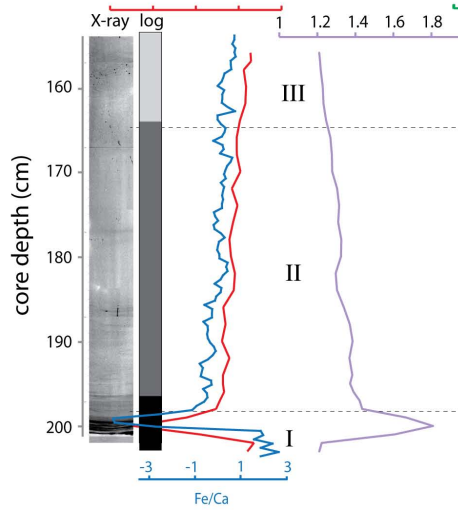

c: Turbidite e3-KIg02

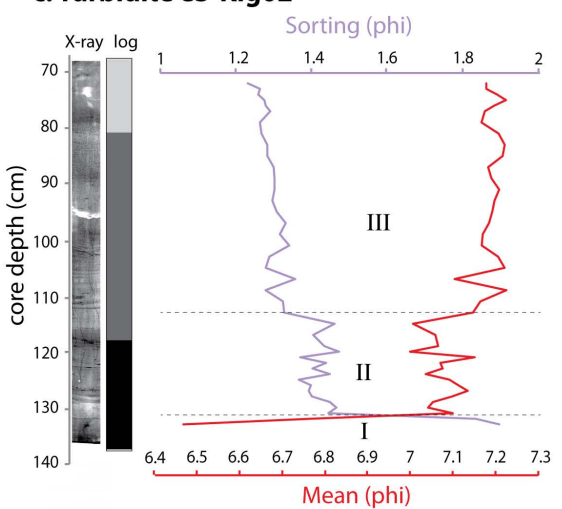

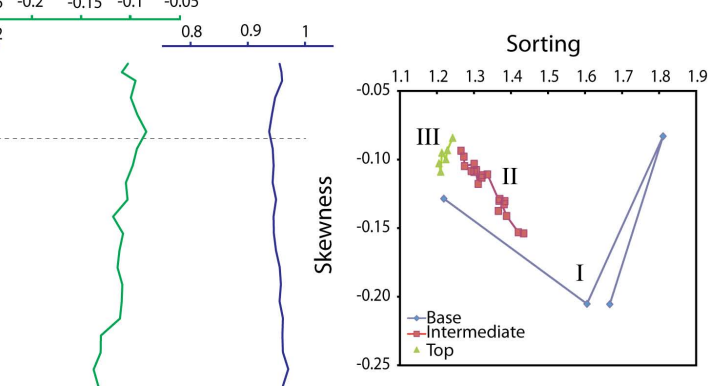

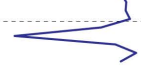

d: Turbidite e5-Klg05

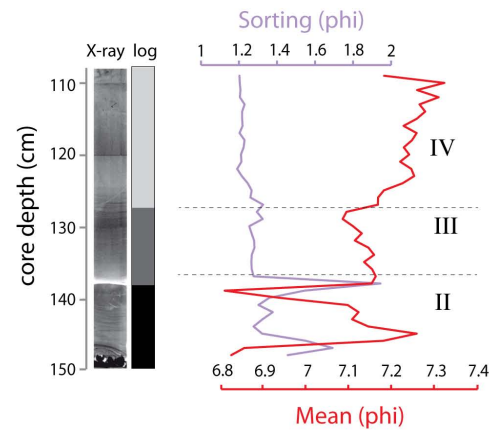

Fig. 3. Characteristics of the thickest turbidites in $\mathrm{Klg} 02$ and $\mathrm{Klg} 05$ cores by using X-ray, log, grain size and geochemical parameters.

The magnetic susceptibility measurements were performed on the split cores using a Bartington MS2E sensor with $5 \mathrm{~mm}$-interval at room-temperature. The data provide a first-order identification of layers enriched in coarse detrital material $(\mathrm{Fe}, \mathrm{Mg}, \mathrm{Ti})$, which can characterize the base of turbidites (Butler, 1992; Tauxe, 2010). Microgranulometric analyses were performed on bulk sediment sub-samples from u-channels at $10 \mathrm{~mm}$-intervals using a Malvern mastersizer 2000. Percentages of clay, silt and sand particles were computed as well as mode, median, mean, skewness and kur- tosis indices (Folk, 1968). The data help to characterize turbidites in terms of depositional processes (Pettijohn et al., 1987; Sperazza et al., 2004).

\subsection{XRF}

XRF data collected by X-ray fluorescence on an Avaatech XRF core scanner were used to correlate cores between the basins and the Western High and to refine sedimentological and geochemical processes associated with 


\section{klg05}

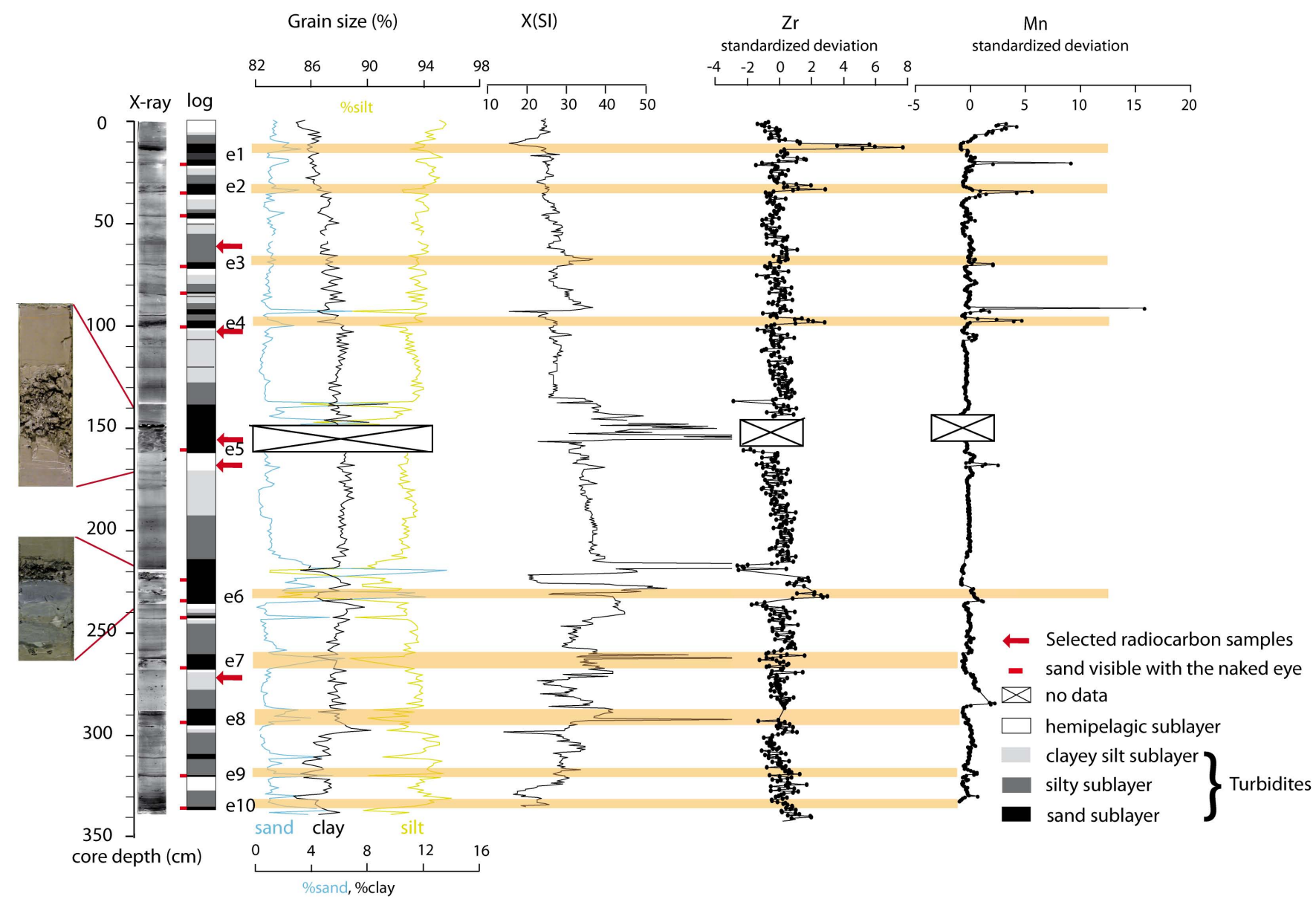

Fig. 4. Stratigraphic log of the Klg05 core in the Tekirdağ Basin obtained by combining X-ray imagery, grain size, magnetic susceptibility data, $\mathrm{Mn}$ and $\mathrm{Zr}$ standardized intensities. On the left, zoom pictures of the two basal layers of the thickest turbidites with gravel are presented. Main deposited turbidites are identified and labelled; event labels change according to their stratigraphic position, beginning with 1 at the top of the core. Sandy sublayers are depicted in black, intermediate silty sublayers in grey, upper clay-rich sublayer in light grey and background sedimentation in white.

turbiditic deposition. The split-core sections were measured every $5 \mathrm{~mm}$, with energies of fluorescence radiation of $10 \mathrm{keV}$ and $30 \mathrm{keV}$ to reach a large spectra of elements, comprising $\mathrm{Al}, \mathrm{Si}, \mathrm{S}, \mathrm{Cl}, \mathrm{K}, \mathrm{Ca}, \mathrm{Ti}, \mathrm{Mn}, \mathrm{Fe}, \mathrm{Br}, \mathrm{Pb}, \mathrm{Rb}, \mathrm{Sr}, \mathrm{Zr}$. The elemental distributions, initially expressed in counts per second, were standardized to get a better comparison of the variations of intensity through the different cores. As intensities are only a semi-quantitative measurement of the real elemental composition, we used ratios that provide the most easily interpretable signal of relative changes in chemical composition, and minimize the risk of drawing erroneous conclusions from XRF data (Palike et al., 2001; Vlag et al., 2004; Bahr et al., 2005). The $\mathrm{Ca} / \mathrm{Ti}$ ratio was exploited, because it represents autochthonous productivity in the sea $(\mathrm{Ca})$, with respect to terrigenous allochthonous input (Ti), and because it is considered as a reliable proxy in the nearby Black Sea environment (Bahr et al., 2005).

\subsection{Age dating}

AMS ${ }^{14} \mathrm{C}$ dating was performed on foraminifers (planktonic and benthic), bulk sediment and on shells in AEON laboratories and ARTEMIS LMC14 laboratory in the LSCE, Orsay. Sediment accumulation rate for the last century was derived from profiles of excess ${ }^{210} \mathrm{~Pb}$ activity $\left({ }^{210} \mathrm{~Pb} \mathrm{xs}\right) .{ }^{210} \mathrm{~Pb}$ and ${ }^{226} \mathrm{Ra}$ activities were measured using a semi-planar $\gamma$ detector at EPOC at the University of Bordeaux 1 (Schmidt et al., 2009). Activities are expressed in $\mathrm{mBq} \mathrm{g}^{-1}$ and errors are based on 1 standard deviation counting statistics. Excess ${ }^{210} \mathrm{~Pb}$ was calculated by subtracting the activity supported by its parent isotope, ${ }^{226} \mathrm{Ra}$, from the total ${ }^{210} \mathrm{~Pb}$ activity in 


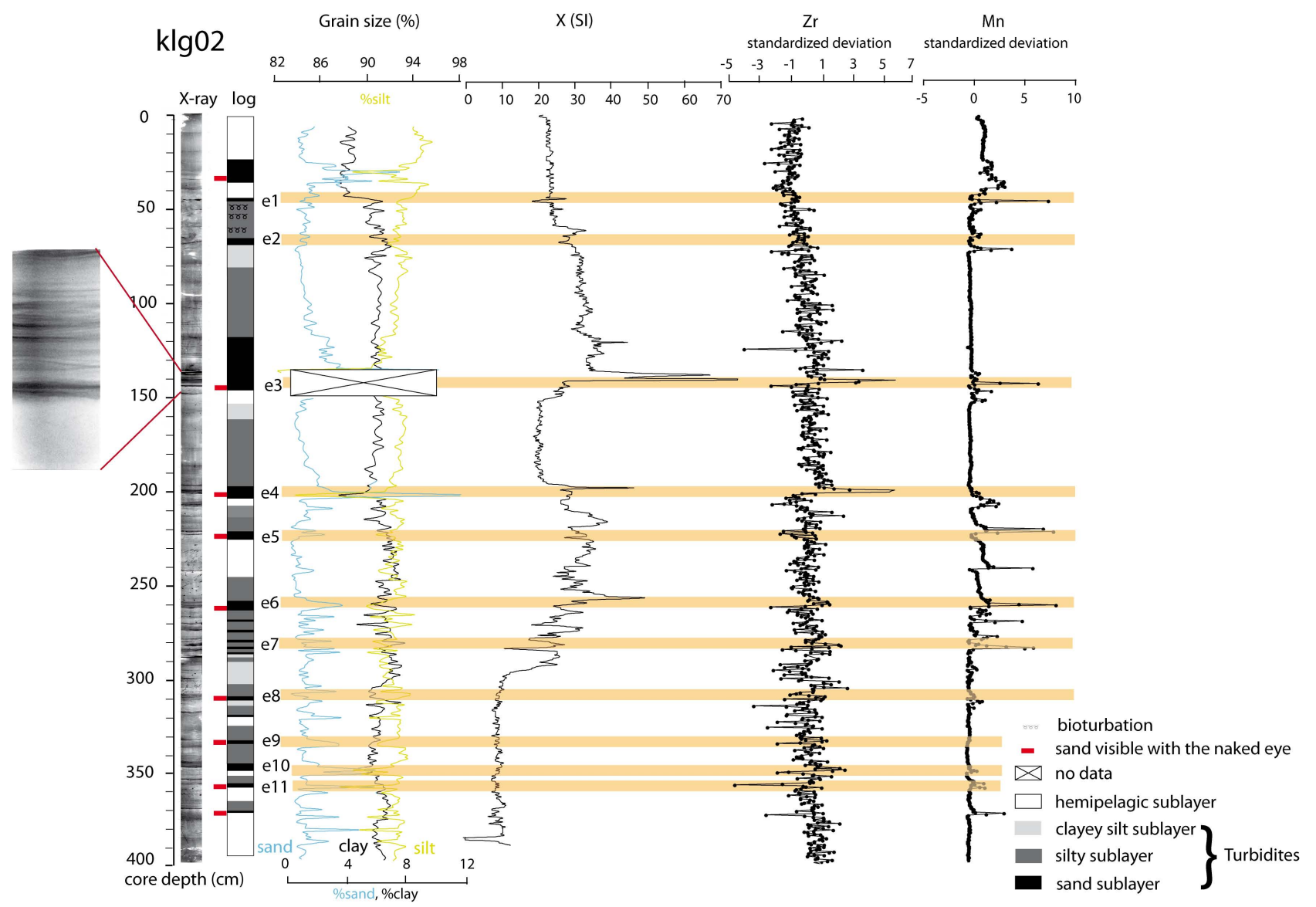

Fig. 5. Stratigraphic log of the Klg02 core in the Central Basin obtained by combining X-ray imagery, grain size, magnetic susceptibility data, $\mathrm{Mn}$ and $\mathrm{Zr}$ standardized intensities. On the left, zoom in the X-ray of the basal layers of the thickest turbidite e3 with complex laminations. Main turbidites deposits are identified and labelled; event labels change according to their stratigraphic position, beginning with 1 at the top of the core. Sandy sublayers are represented in black, intermediate silty sublayers in grey, upper clay-rich sublayers in light grey and background sedimentation in white.

the sediment. Errors in ${ }^{210} \mathrm{~Pb}_{\mathrm{xs}}$ were calculated by propagation of errors in the corresponding pair $\left({ }^{210} \mathrm{~Pb}\right.$ and $\left.{ }^{226} \mathrm{Ra}\right)$. The sedimentation rates were calculated from ${ }^{210} \mathrm{~Pb}_{\mathrm{Xs}}$ profiles, using the constant flux - constant sedimentation model (Robbins, 1978):

$\left[{ }^{210} \mathrm{~Pb}_{\mathrm{Xs}}\right]_{z}=\left[{ }^{210} \mathrm{~Pb} \mathrm{xs}_{0} \exp \left(-z \frac{\lambda}{S}\right)\right.$

where $\left[{ }^{210} \mathrm{~Pb}_{\mathrm{Xs}}\right]_{0, z}$ are the activities of excess ${ }^{210} \mathrm{~Pb}$ at surface, or the base of the mixed layer, and depth $\mathrm{z}, \lambda$ the decay constant of ${ }^{210} \mathrm{~Pb}\left(\lambda=0.0311 \mathrm{yr}^{-1}\right)$, and $S$ the sediment accumulation rate.

\section{Results}

\subsection{Main features of sedimentation in the Marmara Sea}

Visual inspection shows that all cores have a very uniform silty-clay lithology, with few sandy laminations and rare gravelly layers containing numerous shells (indicated in red in the Figs. 4, 5, 6). The colour of the cores is predominantly olive green changing into dark grey with sandy laminations.

$\mathrm{X}$-ray imagery shows a succession of dark sub-layers that are progressively grading to a greyer colour (Fig. 3 event e6 in $\mathrm{Klg} 05$ ) and in places to light grey colours (Fig. 3 event 4 in $\mathrm{Klg} 02$ ), defining what we call here a sedimentary event. The thickest dark layers correspond to sandy laminations and to gravelly layers identified during visual inspection. The dark grey, grey to light grey sequences show an important thickness range from $10 \mathrm{~cm}$ to more than $1 \mathrm{~m}$ thick. These sequences form about $80 \%$ of the sedimentary record of cores 


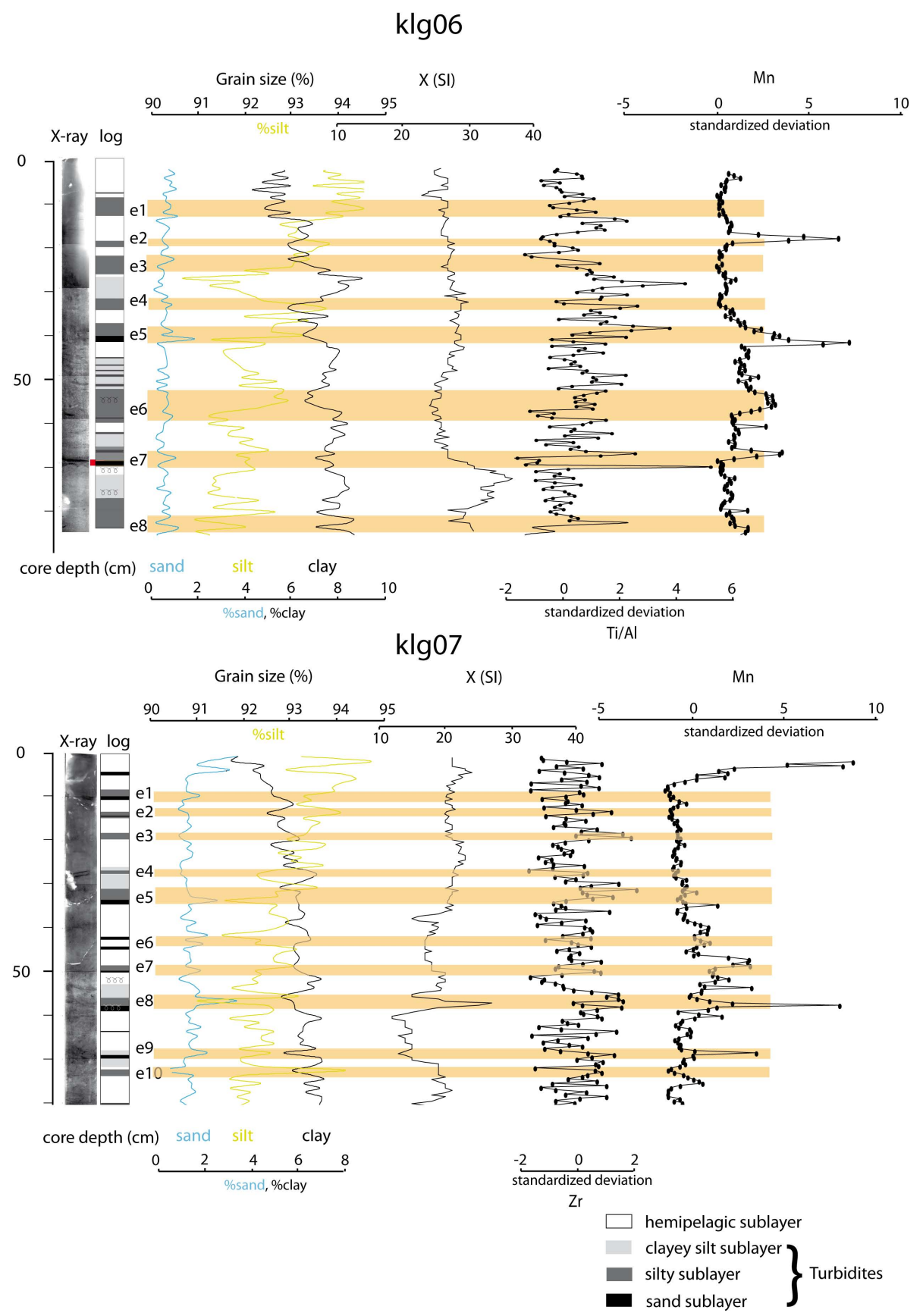

Fig. 6. Stratigraphic $\log$ for the first $80 \mathrm{~cm}$ of the $\mathrm{Klg} 06$ and $\mathrm{Klg} 07$ cores situated in the Western High obtained by combining X-ray imagery, grain size, magnetic susceptibility data, $\mathrm{Mn}$ and Ti/Al or $\mathrm{Zr}$ standardized intensities. Main event deposits are identified and labelled; event labels change according to their stratigraphic position, beginning with 1 at the top of the core. The complete stratigraphic logs are presented in the Appendices (Figs. 12 and 13).

located in deep basins (Klg02, $\mathrm{Klg} \lg 5$ and $\mathrm{Klg} 08)$. X-ray pictures show detailed textural and structural changes in the three sublayers. Dark grey sublayers have a sharp basal surface (Fig. 2: $263 \mathrm{~cm}$ ), which can be wavy, indicating erosion (Figs. 2, 3) and associated with strong structural and cross disturbances (Figs. 2, 4). The overlying, intermediate grey sublayer shows numerous thin parallel laminations in greater concentration near its base (Fig. 3 events e 3 and e4 in $\mathrm{Klg} 02$ and e6 in $\mathrm{Klg} 05$ ), which can be linked to oscillating currents (Beck et al., 2007). The sequence is capped 

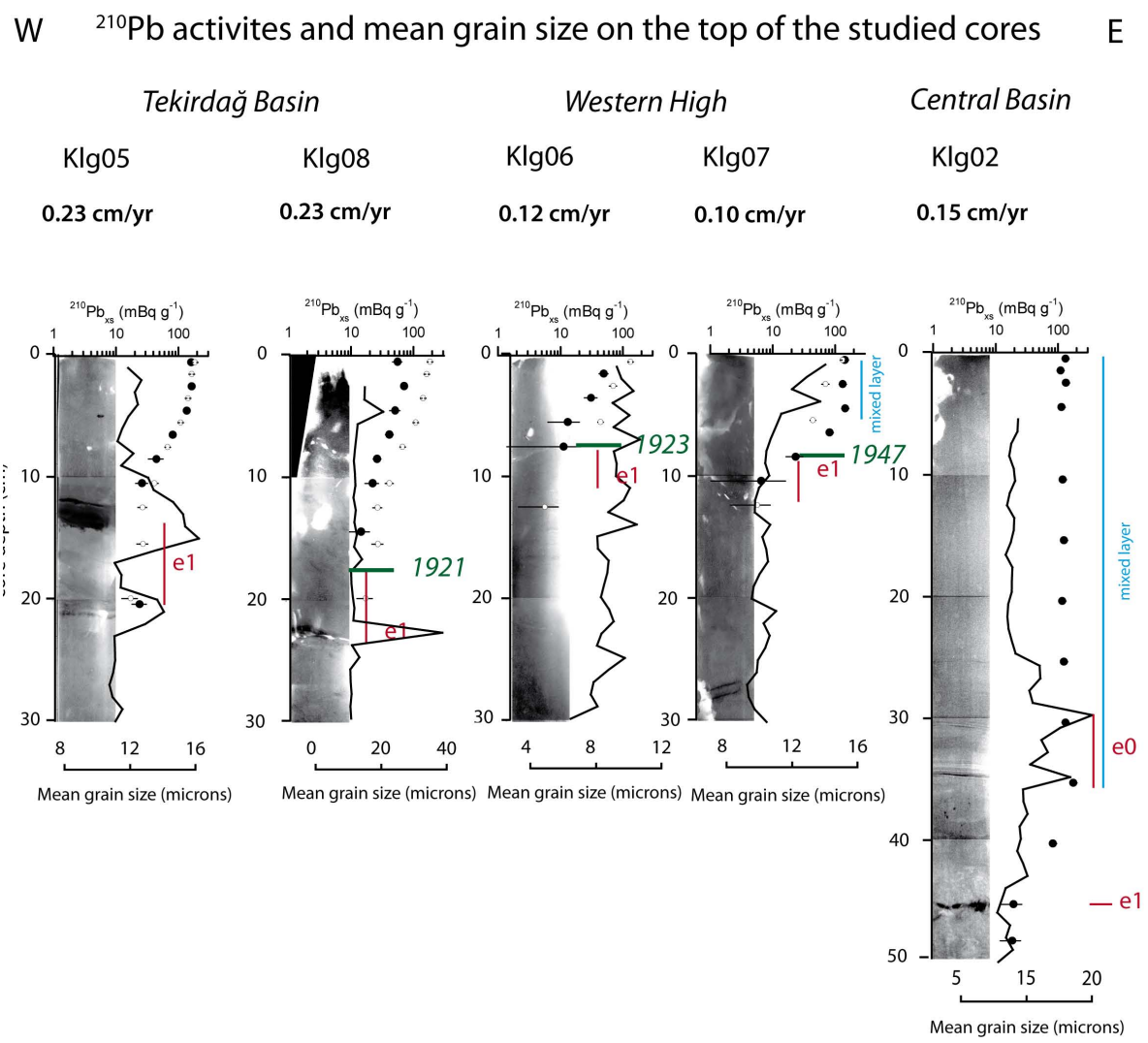

Fig. 7. Excess ${ }^{210} \mathrm{~Pb}$ activities (black dots) and computed sedimentation rates of the cores $\mathrm{Klg} 02, \mathrm{Klg} 05, \mathrm{Klg} 06, \mathrm{Klg} 07$ and $\mathrm{Klg} 08$. White dots are from nearby ROV cores and show that no significant loss of sediments occurs in Klg cores. The extent of the mixed layer is depicted in blue. X-ray imagery associated with the mean grain size (black lines) shows the location of the e1 sedimentary event induced by the $M=7.41912$ earthquake. The age model derived from ${ }^{210} \mathrm{~Pb}_{\mathrm{xs}}$ at the top of the 1912 turbidite is represented in green. Data are given in the Appendices. The event $\mathrm{e} 1$ has the following characteristics:

In Klg05, e1 is marked by two basal sandy layers at 13 and $21 \mathrm{~cm}$ depth, suggesting two distinct mass flows. The thickest upper one is visible with the naked eye and is associated with a significant increase in zirconium and titanium content (Fig. 4). In Klg08 similar sandy layers and geochemical signatures are observed at $18 \mathrm{~cm}$ and $23 \mathrm{~cm}$ depth. In Klg07, the event is marked at 10-11 cm by a small sandy peak, a step increase in silt and an increase in Ti and Mn in XRF record. In Klg06, there is a similar step increase in silt, associated with a dipping white line in the X-ray.

Table 1. Location of Kullenberg cores collected during the Marmascarps mission in 2002.

\begin{tabular}{lccccc}
\hline Basin & Core & Latitude $\left({ }^{\circ} \mathrm{N}\right)$ & Longitude $\left({ }^{\circ} \mathrm{E}\right)$ & Water depth $(\mathrm{m})$ & Core length $(\mathrm{cm})$ \\
\hline Tekirda $\breve{g}$ & $\mathrm{k} l g 05$ & $40^{\circ} 48,50$ & $27^{\circ} 37,3$ & 1123 & 341 \\
Tekirdağ & $\mathrm{k} \lg 08$ & $40^{\circ} 47,31$ & $27^{\circ} 33,22$ & 1111 & 385 \\
Western High & $\mathrm{k} \lg 06$ & $40^{\circ} 48,90$ & $27^{\circ} 44,28$ & 726 & 371 \\
Western High & $\mathrm{k} \lg 07$ & $40^{\circ} 49,115$ & $27^{\circ} 54,44$ & 1065 & 432 \\
Central & $\mathrm{k} \lg 02$ & $40^{\circ} 50,28$ & $28^{\circ} 00,54$ & 1266 & 403 \\
\hline
\end{tabular}


by a light-grey sublayer with possible traces of bioturbation (Figs. 2, 3-Klg05). Similar events were already described in the Marmara Sea by using X-ray images, and were interpreted as the sedimentary rework of major earthquakes (McHugh et al., 2006; Beck et al., 2007).

Grain size measurements are similar for all cores, with a dominance of silt-sized particles. Sieving shows that siltsized particles are a mixture of mineral grains, different kinds of shells including foraminifers, marine and terrestrial organic material, among others. A systematic trend is observed in the upper part of cores characterized by a progressive increase in the percentage of silt-sized particles and a coeval decrease in the percentage of clay-sized particles (Fig. 2). All cores show multiple fine-grained sand deposits that systematically match with the dark sublayers identified in Xray imagery and with high values in magnetic susceptibility, $\chi$ (Figs. 4, 5). In the overlying grey sublayer, silt usually reaches a maximum just above the sand layer, and slowly decreases upward to a minimum or stays nearly constant. The top light grey sublayer shows a relative increase in clay compared to silt. We thus interpret sedimentary events composed of (1) a basal sandy sublayer possibly erosive, (2) an intermediate laminated silt sublayer overlain by (3) an upper clayey silt sublayer with some bioturbation as major turbidites. We also identify in the cores very thin sand lamina that could correspond to minor turbidites. They typically have less than half of the volume of the smallest major turbidite identified in the same core.

To constrain the depositional pattern of the major turbidites, their textural characteristics are accessed by computing distribution parameters like mean, sorting, skewness, and kurtosis (Folk 1968; Fig. 3 e6-Klg05 and e4-Klg02). Major sandy turbidites have the following characteristics: (1) the basal layer of the turbidites often shows multiple pulses, and (2) grain size change between the sand and the silt sublayers is abrupt, (3) change in grain size, sorting and skewness can also be abrupt in the silt and clayey silt sublayers, whereas the decrease in kurtosis is generally gradual. The top clayrich part of the turbidite is marked by a minima in sorting and a skewness around zero.

The major turbidites have also a distinct XRF signature. They typically show a local increase in zirconium $(\mathrm{Zr})$ content (Figs. 2b, 4). The sand sublayers are characterized by a decrease in bromine $(\mathrm{Br})$ content, whereas a relative increase in titanium (Ti) is observed in both the underlying sandy and silt-rich sublayers. Manganese (Mn) shows a sharp increase just below the basal sandy sublayer. The transition to the hemipelagic sedimentation is marked by a rising until a maximum in $\mathrm{K}, \mathrm{Ca}$ or in $\mathrm{Ca} / \mathrm{Ti}$ ratio. These elements do occur in proportion to the hemipelagic sedimentation (Fig. 8). Minor turbidites do not have a noteworthy XRF signature.

The stratigraphic logs of cores presented in Figs. 4, 5, 6 show the X-ray intensities, the magnetic susceptibility, the granulometric measurements and XRF data. The dark Zr enriched sand base, the laminated grey silt sublayer and the clayey silt top sublayers are shown with different grey scale colours, and labelled downward from the top of the core. Minor turbidites are not labelled.

\subsection{Specific features of each site}

In the Tekirdağ Basin, the $350 \mathrm{~cm}$ long sedimentary record of the core Klg05 (Fig. 4) shows ten major turbidites. Sedimentary events are characterized by (1) a sharp sand sublayer with $\chi$ and/or Zr peaks overlain by lamina, (2) an increase in Ti content in the basal and silt sublayers, and (3) a Mn peak beneath the basal sand. Standing alone, thin sandy layers are interpreted as minor turbidites. The largest turbidites labelled e 5 and e 6 at $160 \mathrm{~cm}$ and $233 \mathrm{~cm}$ depth have a gravelly base and a respective thickness of $55 \mathrm{~cm}$ and $70 \mathrm{~cm}$ (zoom pictures on Fig. 4). To assess the depositional pattern of these turbidites, distribution parameters (mean, sorting, skewness, kurtosis) are calculated and divided in layers labelled I, II, III and IV (Fig. 3). Above the gravelly base, event e5 shows successively two sandy peaks: an inverse grading in the silty sublayer (mean size in phi decreases in Fig. 3), followed by an abrupt change in mean-sorting indexes, then by normal grading. In event e6, the two basal sandy peaks (I in Fig. 3) are overlain by a first fining upward sublayer with gradually decreasing sorting and increasing skewness (layer II). Layer II is capped by additional sublayers, with nearly constant mean, skewness and sorting separated by an abrupt change (III and IV in Fig. 3). In the sorting-skewness diagram, grain size evolves gradually towards smaller skewness and better sorting values, but with distinctive groups representing the different sublayers. The geochemical evolution of the two turbidites also show coeval changes with the granulometry (Fig. 3). K intensity shows a gradual evolution through the turbidite similar to the kurtosis index and might reflect a relative increase in illite in the grain assemblage. The characteristics of events 5 and 6 , in particular, non-gradual changes in grain size and the two coarser basal pulses are representative of other major turbidites recorded in $\mathrm{Klg} 05$.

In the inner part of the Central Basin, the core $\mathrm{Klg} 02$ shows eleven major turbidites (Fig. 5), which display a greater diversity in their geochemistry and textural patterns than in $\mathrm{Klg} 05$. The observed diversity may reflect a larger variability in the emplacement and in the sources of turbidites in the inner Central Basin compared to the Tekirdağ Basin. Our identification of major turbidites was based on disturbances identified in the X-Ray images combined with granulometric and geochemical data, suggesting sudden detrital input. Like in $\mathrm{Klg} 05$ there are two large turbidites labelled e 3 and e4, occurring at $150 \mathrm{~cm}$ and $205 \mathrm{~cm}$ depth with a respective thickness of $70 \mathrm{~cm}$ and $50 \mathrm{~cm}$. The shallowest e3 turbidite presents a gravelly base associated with a strong $\chi$ peak (layer I in Fig. 3 and Fig. 5). The overlying deposit shows a gradual decrease in $\chi$ with two distinct phases. The silty sublayer (labelled II in Fig. 3) shows small variations in mean and in sorting without trend, except at the boundary 


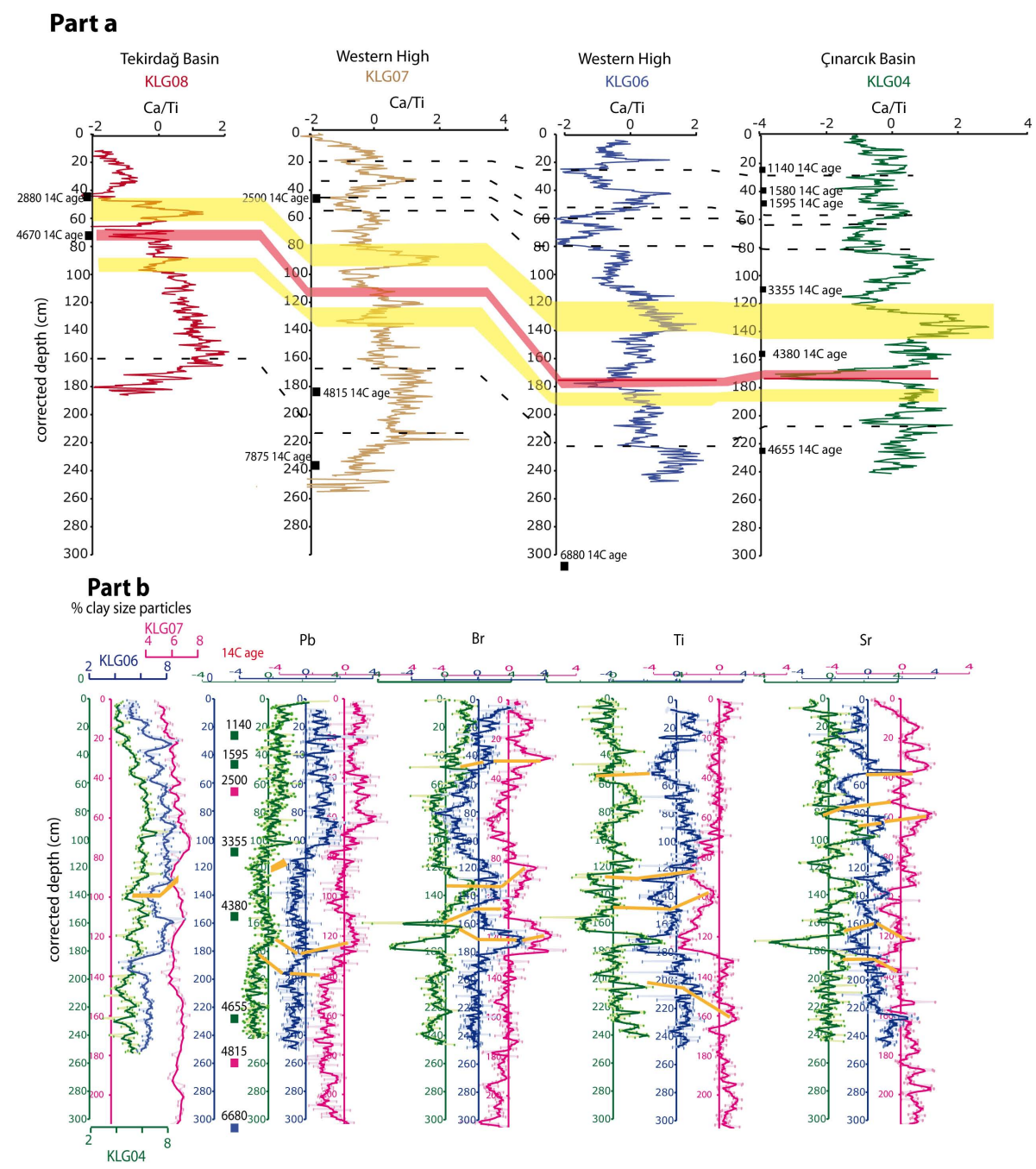

Part c

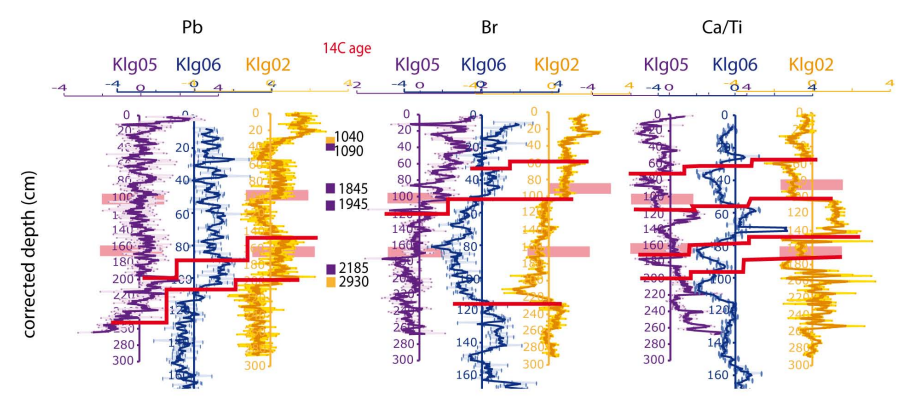

Fig. 8. Correlation of different cores based on XRF and granulometric data. All basal sandy layers have been removed. a: Ca/Ti ratio profiles for cores Klg08 (red curve), Klg07 (brown curve), Klg06 (blue curve) and Klg04 (green curve). Uncalibrated 14 C yr BP are indicated on the left of the profiles (Table 2). Dashed black lines represent correlative highs or lows. b Profiles(from left to right) of clay-sized particles and of the standardized XRF data for $\mathrm{Pb}, \mathrm{Br}$, Ti and $\mathrm{Sr}$ for cores Klg04 (green curve), Klg06 (blue curve) and Klg07 (pink curve). Bold orange lines represent correlative highs or lows. c Profiles of the standardized XRF data with from the left to the right $\mathrm{Pb}, \mathrm{Br}$ and $\mathrm{Ca} / \mathrm{Ti}$ ratio for the cores Klg02 (yellow curves), Klg05 (purple curves) and Klg06 (blue curves). Bold red lines represent key points of correlation. Pink rectangles indicate the location of the top fine-grained of the largest turbidites in Klg05 and Klg02. 
of the overlying clayey-silt sublayer characterized by step changes in all parameters. This top layer (III in Fig. 3) is characterized by increased sorting and a constant mean grainsize. The other large event $\mathrm{e} 4$ has a sandy base with multiple laminations (I in Fig. 3) and a strong $\chi$ peak. The overlying layers II and III present an atypical very low $\chi$ with very little geochemical changes (see Fe/Ca in Fig. 3), and are similar to homogenites documented by Bertrand et al. (2008). Above the basal laminated layer, kurtosis and mean do not change significantly, whereas skewness and sorting have similar but very gradual evolutions. In the sorting-skewness diagram, the data are similar to the e 6 turbidite in $\mathrm{Klg} 05$, with a gradual evolution toward better sorting values and smaller skewness except at the top.

In the Western High, the granulometric trends in Klg06 and $\mathrm{Klg} 07$ cores differ from the cores in the basins (Fig. 6). Sand-sized particles are less than $1 \%$ with few peaks. The major part of the signal comes from the silt-sized particles profile, which is between $94 \%$ and $90 \%$. We focus on the top $80 \mathrm{~cm}$ of the cores in Fig. 6, but complete data are included in the Supplemental Data. In Klg06 we identified eight silt turbidites in the X-ray imagery that correspond to a punctual upward increase in grain size capped by a relative increase in clay (Fig. 6). The layers are associated with manganese peaks and an increase in Ti/Al ratio. The two thickest and most distinctive silt turbidites (labelled e5 and e7) are recorded at a depth of $58 \mathrm{~cm}$ and $85 \mathrm{~cm}$. The e5 turbidite has the largest sand peak and e7 is associated with the only distinct magnetic susceptibility peak in the core. Both turbidites have a strong XRF signature, characterized by an increase in the Ti/Al ratio in the main body and a marked increase in manganese content beneath.

In the core $\mathrm{Klg} 07$, ten fine-grained turbidites were recognised. These turbidites are thin and are identified based on faint disturbances in the X-ray imagery, grain-size changes, $\chi$ peaks and geochemical spikes in $\mathrm{Zr}$, Sr/Ca and Mn (Fig. 6). Four turbidites (labelled e1, e5, e 8 and e9) at $10 \mathrm{~cm}, 32 \mathrm{~cm}$, $58 \mathrm{~cm}$ and $69 \mathrm{~cm}$ in depth have a sandy base. Events e5 and e8 correspond to the largest events and show zirconium, manganese and magnetic susceptibility peaks.

\subsection{Age constraints}

\subsubsection{Excess ${ }^{210} \mathbf{P b}_{\mathbf{x s}}$ activities}

The age of sediments in the first 20 to $50 \mathrm{~cm}$ of all cores was constrained by using unsupported lead data. Excess ${ }^{210} \mathrm{~Pb}$ activities for each core are consistent with the activities of the nearby ROV cores recovered during the same cruise (Fig. 7). In the first $10 \mathrm{~cm}$ of cores $\mathrm{Klg} 05, \mathrm{Klg} 08$ and $\mathrm{Klg} 06,{ }^{210} \mathrm{~Pb}_{\mathrm{Xs}}$ activities present an exponential decay with increasing depth with no evidence of reworking, as confirmed by X-ray imagery. The limited shift between ROV and $\mathrm{Klg}$ profiles indicates a moderate loss of surface sediment, up to $6 \mathrm{~cm}$ for $\mathrm{Klg} 08$ during coring. The ${ }^{210} \mathrm{~Pb}$ derived sedimentation rates are $0.23 \mathrm{~cm} \mathrm{yr}^{-1}$ for Tekirdağ Basin $(\mathrm{Klg} 08$ and
Table 2. AMS radiocarbon dating results performed on bivalve shell fragments (sh), bulk sediment (total organic carbon + total inorganic carbon) (bk), benthic (bf) and planktonic (plc) foraminifers. Sample names written in italics are considered to be reworked and were not used for the data interpretation. Analyses were performed at Artemis LMC14 laboratory and AEON laboratories; 14C dating has not been calibrated and corrected for reservoir effect.

\begin{tabular}{|c|c|c|c|}
\hline Sample & Type & Age (yr BP) & Error $( \pm y r)$ \\
\hline$K l g 02,180 \mathrm{~cm}$ & bk & 4830 & 20 \\
\hline$K l g 02,185 \mathrm{~cm}$ & bk & 3430 & 20 \\
\hline $\mathrm{Klg} 02,352 \mathrm{~cm}$ & bk & 5060 & 20 \\
\hline $\mathrm{K} \lg 03,114 \mathrm{~cm}$ & plc & 2380 & 15 \\
\hline $\mathrm{K} \lg 03,114 \mathrm{~cm}$ & bf & 1630 & 30 \\
\hline $\mathrm{Klg} 03,158 \mathrm{~cm}$ & $\mathrm{sh}$ & 2370 & 30 \\
\hline $\mathrm{K} \lg 03,161 \mathrm{~cm}$ & plc & 2370 & 60 \\
\hline $\mathrm{K} \lg 05,48 \mathrm{~cm}$ & bf & 1090 & 15 \\
\hline$K l g 05,94 \mathrm{~cm}$ & bk & 3070 & 20 \\
\hline$K l g 05,102 \mathrm{~cm}$ & bk & 3110 & 20 \\
\hline $\mathrm{K} \lg 05,103 \mathrm{~cm}$ & bf & 1845 & 15 \\
\hline$K l g 05,146 \mathrm{~cm}$ & bk & 3870 & 20 \\
\hline $\mathrm{Klg} 05,152 \mathrm{~cm}$ & $\operatorname{sh}$ & 1945 & 30 \\
\hline $\mathrm{Klg} 05,167 \mathrm{~cm}$ & bf & 1735 & 30 \\
\hline Klg05, $178 \mathrm{~cm}$ & sh & 35790 & 330 \\
\hline$K l g 05,217 \mathrm{~cm}$ & bk & 5180 & 20 \\
\hline$K l g 05,220 \mathrm{~cm}$ & sh & 13700 & 45 \\
\hline$K l g 05,229 \mathrm{~cm}$ & $\operatorname{sh}$ & 39480 & 490 \\
\hline$K l g 05,234 \mathrm{~cm}$ & $\mathrm{sh}$ & 14390 & 50 \\
\hline $\mathrm{K} \lg 05,250 \mathrm{~cm}$ & plc & 2185 & 20 \\
\hline $\mathrm{Klg} 05,250 \mathrm{~cm}$ & bf & 2445 & 25 \\
\hline Klg05, $261 \mathrm{~cm}$ & bk & 4180 & 20 \\
\hline$K l g 06,278 \mathrm{~cm}$ & $\mathrm{sh}$ & 33870 & 270 \\
\hline $\mathrm{Klg} 06,366 \mathrm{~cm}$ & plc & 6880 & 120 \\
\hline $\mathrm{K} \lg 07,61 \mathrm{~cm}$ & plc & 2500 & 30 \\
\hline $\mathrm{Klg} 07,212 \mathrm{~cm}$ & plc & 4815 & 45 \\
\hline $\mathrm{K} \lg 07,255 \mathrm{~cm}$ & $\mathrm{sh}$ & 7390 & 30 \\
\hline $\mathrm{Klg} 07,297 \mathrm{~cm}$ & sh & 7875 & 35 \\
\hline$K l g 08,73 \mathrm{~cm}$ & sh & 2880 & 30 \\
\hline$K l g 08,90 \mathrm{~cm}$ & $\operatorname{sh}$ & 30200 & 180 \\
\hline$K l g 08,117 \mathrm{~cm}$ & sh & 28880 & 150 \\
\hline Klg08, $124 \mathrm{~cm}$ & sh & 12850 & 40 \\
\hline$K l g 08,145 \mathrm{~cm}$ & sh & 4670 & 30 \\
\hline$K l g 08,150 \mathrm{~cm}$ & $\operatorname{sh}$ & 21380 & 80 \\
\hline$K l g 08,220 \mathrm{~cm}$ & sh & 30160 & 180 \\
\hline$K l g 08,326 \mathrm{~cm}$ & sh & 39820 & 510 \\
\hline$K l g 08,355 \mathrm{~cm}$ & sh & 12770 & 45 \\
\hline
\end{tabular}

$\mathrm{Klg} 05$ ), and $0.12 \mathrm{~cm} \mathrm{yr}^{-1}$ for Western High (Klg06). These rates are interpreted to represent steady hemipelagic sedimentation rates.

The uppermost section of the cores $\mathrm{Klg} 02$ and $\mathrm{Klg} 07$ shows constant ${ }^{210} \mathrm{~Pb}_{\mathrm{Xs}}$ activities in an inferred mixed layer. In core $\mathrm{K} \lg 02$, the $35 \mathrm{~cm}$ thick mixed layer is identical to the ${ }^{210} \mathrm{~Pb}$ trend in the nearby core C4, studied in McHugh et al. (2006) 
(Fig. 1), and is associated with two, thin, sandy turbidites visible in the X-ray imagery and in the granulometric data. We have no explanation for the origin of this mixed layer. In core $\mathrm{Klg} 07$, the mixed layer is only $5 \mathrm{~cm}$ thick. In the nearby $20 \mathrm{~cm}$ long core collected using a ROV, there is no mixed layer, which suggests that it is a coring artefact. Below the mixed layer, ${ }^{210} \mathrm{~Pb}$ activity shows a rapid exponential decay with depth. The inferred background hemipelagic sedimentation rate is $0.15 \mathrm{~cm} \mathrm{yr}^{-1}$ in $\mathrm{Klg} 02$ (Central Basin) and is $0.10 \mathrm{~cm} \mathrm{yr}^{-1}$ in $\mathrm{Klg} 07$ (Western High), similar to the $\mathrm{Klg} 06$ rate.

\subsubsection{Radiocarbon age dating}

Radiocarbon age dating shows globally a large disparity depending on the material used (shells, bulk sediment and foraminifers) (Table 2). Ages calculated from shells in cores $\mathrm{Klg} 05, \mathrm{Klg} 08$ and $\mathrm{Klg} 06$ generally overestimate the expected age of the host sediment, and indicate significant reworking and external sedimentary supply from the shelf associated with turbiditic deposition. Ages of bulk sediments (total organic carbon and total inorganic carbon) are also too old and are not further discussed. Ages obtained from both planktonic and benthic foraminifers extracted on the top of turbiditic events are the most reliable and thus form the basis for our chronology.

Planktonic foraminifers were obtained in sufficient abundance to be dated only at a few locations; so benthic foraminifers were also dated. To further constrain our age model, we correlate our records with nearby published sedimentary cores. In the Western High, by comparing the Klg06 core to the core MD2430 studied by Vidal et al. (2010), the Younger Dryas transition would be below the core bottom, which is in agreement with the obtained uncalibrated age of $6880 \mathrm{yr} \mathrm{BP}$ at the core bottom. The Klg07 core also in the Western High has magnetic susceptibility measurements similar to the core MD2430, and uncalibrated radiocarbon ages of $2500 \mathrm{yr} \mathrm{BP}$ at $61 \mathrm{~cm}$ depth, $4815 \mathrm{yrBP}$ at $212 \mathrm{~cm}$ depth and $7875 \mathrm{yr} \mathrm{BP}$ at $297 \mathrm{~cm}$ depth, compatible with the age model of the MD2430 core (Fig. S4 in the appendices; Vidal et al. 2010). The $\mathrm{Klg} 05$ and $\mathrm{Klg} 02$ cores in the basins can be correlated to the $\mathrm{C} 4$ and $\mathrm{C} 8$ cores of McHugh et al. (2006). In Klg05, the uncalibrated ages of $1090 \mathrm{yr} \mathrm{BP}$ at $48 \mathrm{~cm}$ depth, $1735 \mathrm{yr} \mathrm{BP}$ at $167 \mathrm{~cm}$ depth and $2185 \mathrm{yr} \mathrm{BP}$ at $250 \mathrm{~cm}$ depth agree with the 14C-age of $1320 \mathrm{yr} B P$ at $55 \mathrm{~cm}$ depth and $1460 \mathrm{yr}$ BP at $65 \mathrm{~cm}$ depth in core C4 (Fig. S2 in the appendices; McHugh et al. 2006). The Klg08 core has $14-\mathrm{C}$ ages of $2880 \mathrm{yr} \mathrm{BP}$ at $73 \mathrm{~cm}$ depth, $4670 \mathrm{yr}$ BP at $145 \mathrm{~cm}$ depth and $12770 \mathrm{yr} \mathrm{BP}$ at $335 \mathrm{~cm}$ depth (Fig. S1).

The longest records (spanning 6000 to $12000 \mathrm{yr}$ ) are reached in the Western High and on the uplifted side of the NAF in the Tekirdağ Basin. In the Tekirdag and Central Basins, we have a sedimentary record lasting 3000 to $4000 \mathrm{yr}$.

\section{Interpretation}

\subsection{Variations in sedimentation pattern in the Marmara Sea}

The correlation of the $\mathrm{Klg} 02$ to $\mathrm{Klg} 08$ cores across the whole Marmara Sea was done by combining granulometry, $\mathrm{Ca} / \mathrm{Ti}$ ratio, $\mathrm{Ti}, \mathrm{Pb}, \mathrm{Br}$ and $\mathrm{Sr}$ intensities with the obtained chronological data. Marked geochemical and granulometric variations are used as chronological markers and are tentatively interpreted as global changes in the sedimentation pattern of the Marmara Sea related to anthropogenic disturbances.

The cores $\mathrm{Klg} 07$ and $\mathrm{Klg} 08$, covering the longest time frame, show similar $\mathrm{Ca} / \mathrm{Ti}$ variations (Fig. 8a). Based on radiocarbon dating and $\chi$ measurements, the $\mathrm{Klg} 07$ core can also be related to the core MD2430, studied in Vidal et al. (2010) (Fig. S4 in the appendices). The base of Klg07 is characterized by high $\chi$ and was deposited at the end of the glacial period (Fig. S4 in the appendices). Between 2 and $3 \mathrm{~m}$ depth, deposits in $\mathrm{Klg} 07$ (characterized by relatively high calcium over titanium ratio) correspond to organic-rich deposits occurring from $11.5 \mathrm{kyr}$ BP to $7 \mathrm{kyr} \mathrm{BP}$ (Çağatay et al., 2000; Vidal et al., 2010). We found a similar high $\mathrm{Ca} / \mathrm{Ti}$ ratio in $\mathrm{Klg} 08$ at $1.6 \mathrm{~m}$. At shallower depths, there is a distinctive thin layer marked by a minimum in $\mathrm{Ca} / \mathrm{Ti}$ ratio in cores $\mathrm{Klg} 08$, Klg07, Klg06 and Klg04 (red layer in Fig. 8a). This layer has a particular geochemical signature, characterized by an anomalous $\mathrm{Rb}$ peak in $\mathrm{Klg} 08$, $\mathrm{Klg} 06$ and $\mathrm{Klg} 04$, associated with high $\mathrm{Zr}$ and low $\mathrm{Ca}$ intensities. This anomalous marker present from the Tekirdağ Basin to the Çınarcık Basin is interpreted as a key correlation marker of unknown origin. At shallower depth there is another correlative layer with a high $\mathrm{Ca} / \mathrm{Ti}$ ratio (yellow upper layer in Fig. 8a). In the uppermost part of the core section, the $\mathrm{Ca} / \mathrm{Ti}$ curves still present high variations that are used to correlate laterally the different cores.

$\mathrm{Pb}, \mathrm{Sr}, \mathrm{Br}$ and $\mathrm{Ti}$ intensities as well as grain size also show correlative downcore variations. These variations are illustrated in Fig. 8b using the core Klg04 in Çınarcık Basin and the cores Klg06 and $\mathrm{Klg} 07$ in the Western High. The upper part of all granulometric profiles show an upward decrease in clay-sized particles coeval to an increase in siltsized particles. The grain size increase is coeval with a step increase in lead and titanium. These recent sedimentological changes point to an increase in the allochthonous terrigenous input in the Marmara Sea. Radiocarbon dating indicates that this increase started around $1200 \mathrm{cal} \mathrm{yr} \mathrm{BC}$. These changes thus occurred during the so-called Beyşehir Occupation Phase (Eastwood et al., 1998), which was documented in Lake Manyas along the southern shore of the Marmara Sea (Kazanci et al., 2004). The phase is characterized by forest clearance, crop cultivation and arboriculture (Van Zeist et al., 1975; Bottema and Woldring, 1994). These modifications in the vegetation cover have triggered high sedimentation rates in lakes and in the southern shelf of 


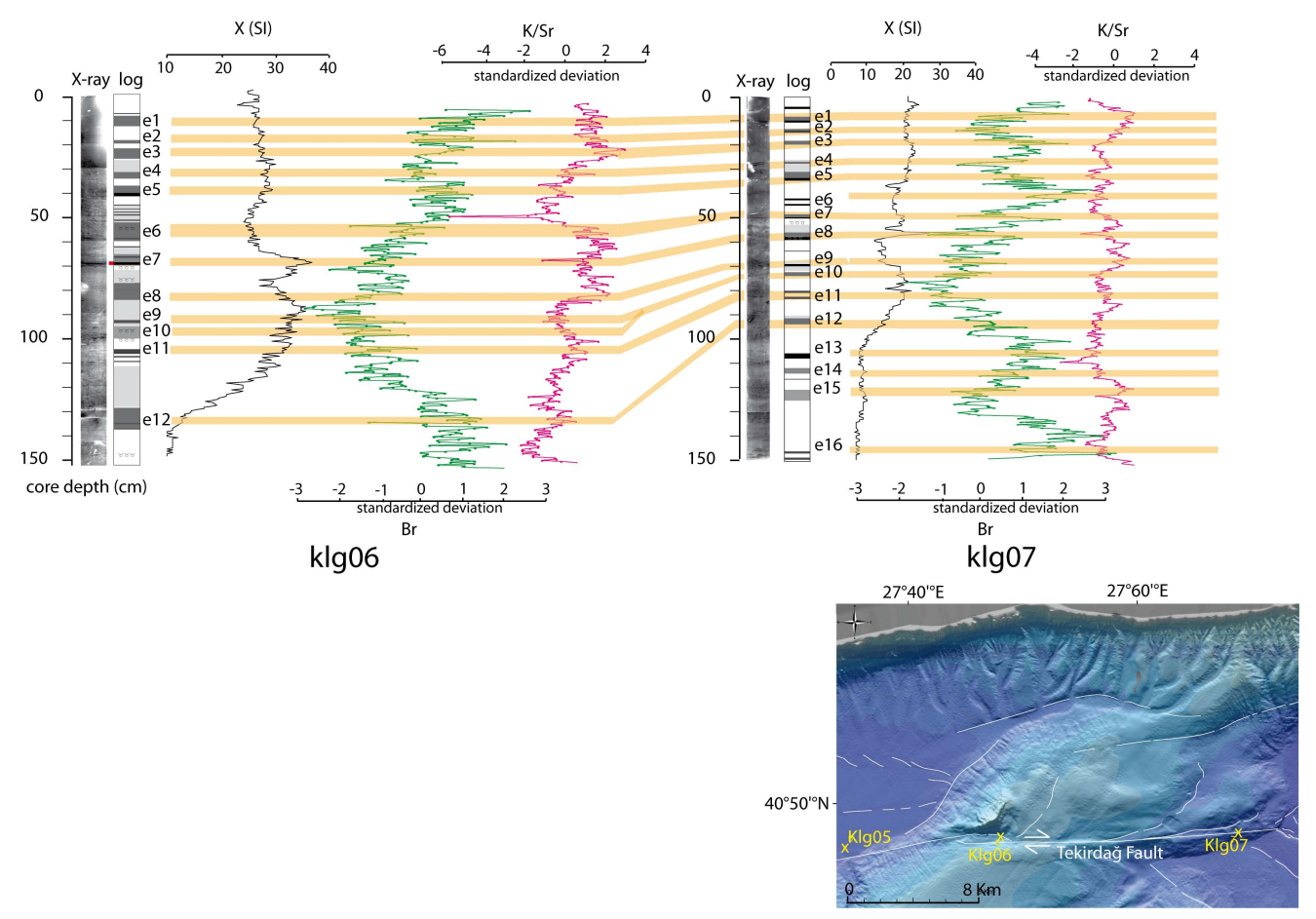

Fig. 9. Core correlation between $\mathrm{K} \lg 06$ and $\mathrm{Klg} 07$ using X-ray, magnetic susceptibility, bromine and $\mathrm{K} / \mathrm{Sr}$ ratio. Increase $\mathrm{Sr}$ at the base of turbidites suggests allochthonous input. On the opposite, increase in $\mathrm{K}$ might reflect higher illite content in the upper clayey-silt sublayer. Localisation of the cores is indicated on the inset map.

the Marmara Sea (Kazanci et al., 2004). Since that time the anthropogenic activity in the watershed of the Marmara Sea has continuously increased. Istanbul (Byzantium) and other major Roman cities on the Marmara shores started developing around $600 \mathrm{BC}$ and expanded when Byzantium became the capital of the Roman Empire in 300 AD. The correlative geochemical and granulometric variations in Fig. 8b are interpreted as being related to the anthropogenic modifications of Marmara watershed. An additional argument supporting this inference is that the observed changes are traceable in the three basins of the Marmara Sea as well as in the Western High.

The correlation of cores $\mathrm{Klg} 02$ and $\mathrm{Klg} 05$ in deep depocenters with other cores is more difficult due to the occurrence of two thick turbidites layers, which distort the signal. The step increase in lead related to the Beyşehir Occupation Phase can still be identified in both cores as well as correlable variations in $\mathrm{Ca} / \mathrm{Ti}$ ratio, $\mathrm{Br}$, Ti, and $\mathrm{Sr}$ intensities (Fig. 8c).

The correlable variations of $\mathrm{Ca} / \mathrm{Ti}$ ratio, $\mathrm{Pb}, \mathrm{Br}, \mathrm{Ti}, \mathrm{Sr}$ intensities and granulometry in different cores are used as chronological markers and allow looking at the synchronicity of identified events. The correlation of the different cores based on XRF matching for all the studied cores is presented in Fig. 10. This correlation is used to derive the results presented in the following sections.

\subsection{Depositional pattern and sedimentation rates in the different basins and high}

The correlation of the Klg cores, spanning the two main sedimentary basins of the Marmara Sea and its Western High, allows drawing conclusions regarding the depositional pattern.

Radiogenic lead data provide a consistent picture of the rate of hemipelagic sedimentation in the eastern and central part of the Marmara Sea. The rates are higher in the basins than on adjacent ridges. The highest value obtained in the Tekirdağ Basin is consistent with the rapid subsidence of the basin near the fault strand described in Seeber et al. (2004), and with specific locations of the cores $\mathrm{Klg} 05$ and $\mathrm{Klg} 08$ near the basin margins, providing continuous terrigenous input.

The mean sedimentation rate can also be inferred since the beginning of the Beyşehir Occupation Phase (marked by a step increase in lead at $1200 \mathrm{cal} \mathrm{yr} \mathrm{BC)} ; 2.85 \mathrm{~m}$ and $3 \mathrm{~m}$ of cumulated sediments have been deposited in the Tekirda $\breve{g}$ Basin at the location of Klg05 and in the Central Basin at the location of $\mathrm{Klg} 02$. The average sedimentation is around $0.09 \mathrm{~cm} \mathrm{yr}^{-1}$ and is dominated by turbiditic deposits representing about $80 \%$ of the sediments. The hemipelagic sedimentation rate cannot be extrapolated to obtain meaningful results by removing turbidite thickness. Most turbidites have an erosive base, which is visible in the X-Ray images. Their 


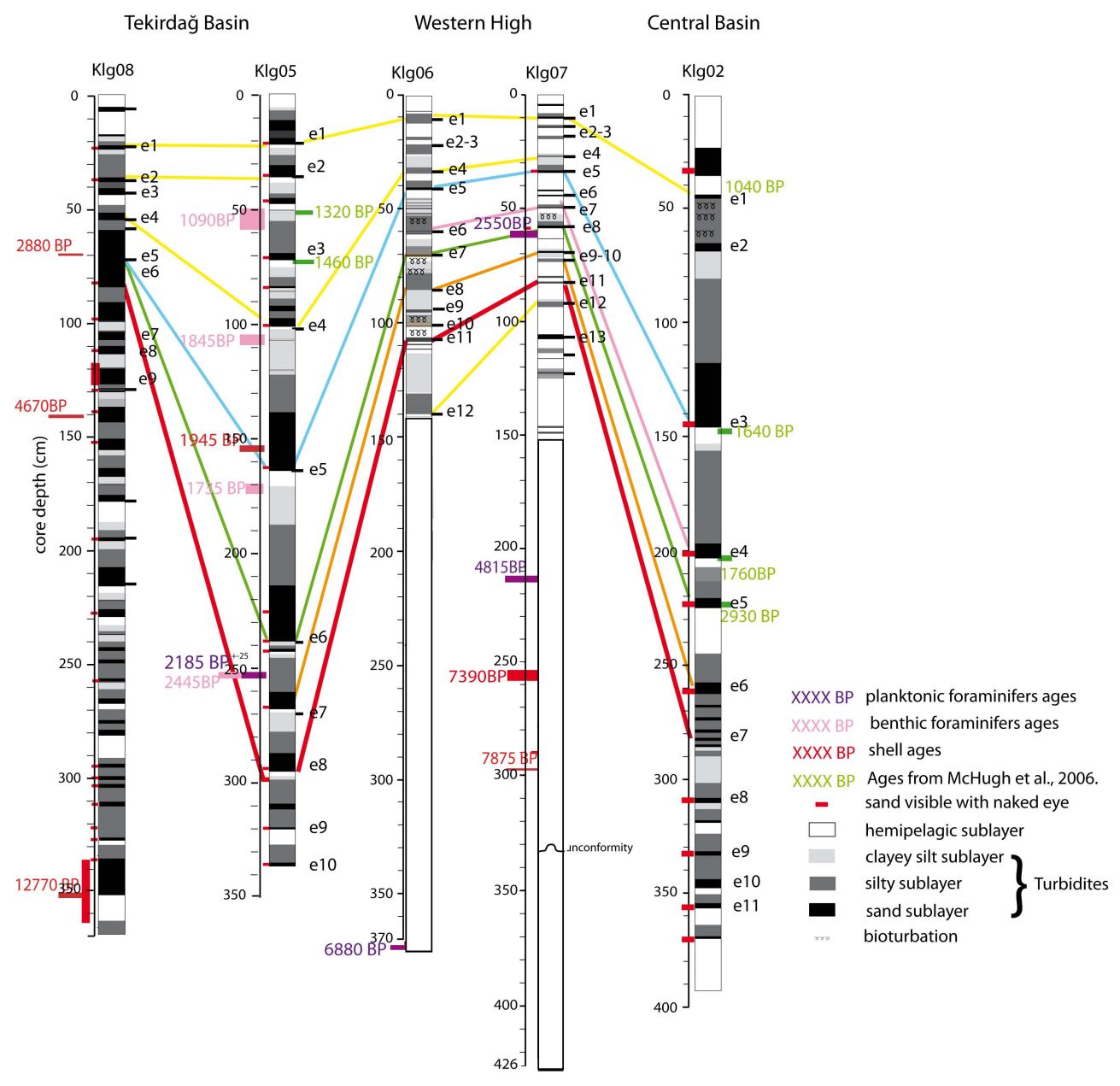

Fig. 10. XRF Correlation obtained in Fig. 8 for the cores Klg08, Klg05, Klg06, Klg07 and Klg02. Lines between cores represent the correlative sedimentary events identified in Figs. 4, 5, 9. Uncalibrated radiocarbon ages for shells (in red), planktonic foraminifers (in purple), benthic foraminifers (in light pink) are presented in Table 2. Radiocarbon ages in green are from McHugh et al. (2006).

emplacement in the basins is thus associated with efficient sedimentary remobilisation characterized by sea floor erosion and incorporation of a significant part of the contemporary sea floor.

An extreme case is $\mathrm{Klg} 08$ core located at the foot of the Tekirdağ slope like Klg05 but on the hanging wall of the Tekirdağ fault. The hemipelagic rates at the Klg08 and Klg05 sites are similar, but the mean sedimentation rate in $\mathrm{Klg} 08$ is more than three times lower than in Klg05. Turbidites are highly erosive at the Klg08 site and are deposited preferentially further north on the down-thrown side of the fault, a local topographic low repeatedly created by earthquake rupture along the Tekirdağ fault. A similar conclusion was reached by Beck et al. (2007) in the Central Basin.

In the Western High, the mean sedimentation rates of cores $\mathrm{Klg} 06$ and $\mathrm{Klg} 07$ are three times lower than in the Tekirdag Basin during the period characterized by high lead intensities starting respectively at the depth of $1.2 \mathrm{~m}$ and $0.8 \mathrm{~m}$ (Fig. $8 \mathrm{~b}$ ).
This is in agreement with the lower hemipelagic rate and the thin fine-grained turbidites deposits.

Finally, the two consecutive thick turbidites (recorded both in the Tekirdağ and the Central Basins) are anomalously large compared to the other turbidites identified and are reminiscent of the homogenites deposited in the lower (preHolocene) lacustrine sequence during a period of high terrigenous accumulation rates on the edges of the Marmara Sea (Beck et al., 2007). The occurrence of these thick urbidites suggests a temporary increase in terrigenous sediment supply, which would have occurred after the Beyşehir Occupation Phase. Once a significant part of the forest cover has been removed and that large-scale urbanisation started, erosion and increased sedimentary transport occurred in the Marmara watersheds. Sediment supply to the Marmara shelves thus increased and larger turbidites were deposited. As the watershed adjusted to the changed environment, sediment supply gradually decreased, and thinner turbidites were 
deposited. These inferences suggest that the thickness of turbidites in the Marmara Sea is controlled by the amount of cumulated unstable sediments on slopes between earthquakes, as well as by the strength of earthquake shaking.

\subsection{Turbidites triggered by the 1912 historical earthquake}

The ${ }^{210} \mathrm{~Pb}$ xs data provide a chronology of the most recent sedimentary events, and thus allow characterizing turbidites triggered by the $1912 M=7.4$ Mürefte earthquake.

The rupture associated with the 1912 earthquake was documented on-land west of the Marmara Sea (Rockwell et al., 2009; Aksoy et al., 2010) and offshore on the Tekirdağ fault (Armijo et al., 2005; Aksoy et al., 2010). Figure 7 indicates that the most recent mass wasting event(called e1) recorded in cores $\mathrm{Klg} 02, \mathrm{~K} \lg 05, \mathrm{Klg} 08, \mathrm{Klg} 06, \mathrm{~K} \lg 07$ occurs at a depth where ${ }^{210} \mathrm{~Pb}_{\mathrm{xs}}$ levels reach minimal meaningful values $\left(10\right.$ to $\left.20 \mathrm{mBq} \mathrm{g}^{-1}\right)$. Considering the interface, ${ }^{210} \mathrm{~Pb}_{\mathrm{Xs}}$ activities of nearby ROV (140 to $170 \mathrm{mBq} \cdot \mathrm{g}^{-1}$ ), and its halflife of $22.3 \mathrm{yr}$, the low values of ${ }^{210} \mathrm{~Pb}_{\mathrm{xs}}$ just above the level of the most recent mass-wasting event would have occurred at 4-5 half-lives or 80 to $100 \mathrm{yr}$. The most recent turbidites in the Tekirdağ Basin and in the Western High are thus interpreted to be related to the 1912 earthquake.

The 1912 turbidite in $\mathrm{Klg} 05$ and $\mathrm{Klg} 08$ cores has two basal sandy layers, which is a characteristic of turbidites deposited at the Klg05 site in the Tekirdağ Basin. The earthquake has also left a sedimentary imprint in the Central Basin, which suggests that the rupture of the Tekirdağ Segment can generate turbidites in the Central Basin. This implies that the two different depocenters of the Marmara Sea, which are the Tekirdağ and the Central Basins, may have the potential to record the same large magnitude earthquake.

\subsection{Origin of turbidites}

The most recent turbidite in the studied cores was generated by the 1912 earthquake and one can wonder if other identified turbidites have a seismic origin. Sediment gravity flows can be produced by a wealth of other processes like storms, wave loading, tsunamis, and sediment loading (Adams, 1990; Goldfinger et al., 2003b). Seismoturbidites have often particular sedimentological imprints like multiple coarse bases, indicating multiple sources (Nakajima and Kanai, 2000; Goldfinger et al., 2008), complex laminations (Shiki et al., 2000; McHugh et al., 2011), flaser beds that are tractive current-induced structures that could be related to seiche motion (Beck et al., 2007), erosional contacts, grain-size breaks and abrupt changes in sedimentary structure (Nakajima and Kanai, 2000; Shiki et al., 2000). They can also have a particular geochemical imprint (Nakajima and Kanai, 2000), with an increase in terrigenous sediment content (McHugh et al., 2011). These criteria are met for all turbidites in $\mathrm{Klg} 05$ and most in $\mathrm{Klg} 02$ (see Sect. 5.2).
The two coarser basal pulses observed in the majority of turbidites in $\mathrm{Klg} 05$ are probably related to flow through separate channels that amalgamate at the site, located near the base of the basin slope. However, as stated by Masson et al. (2011), it is difficult based on sedimentological criteria alone to recognise without ambiguity seismically-generated turbidites. Another key test, commonly used in paleoseismology, is to check the synchronicity of the documented events at different sites within a given structural setting (Goldfinger, 2011). In the following, the synchronicity test is applied to the Kullenberg and the published cores. The test relies on the core correlation obtained by using lithological descriptions, $\chi, \mathrm{XRF}$, granulometric data, radiocarbon and ${ }^{210} \mathrm{~Pb}$ dating. In the Tekirdağ Basin, Klg05 was compared to (1) the C8 core (McHugh et al., 2006) located $3 \mathrm{~km}$ north, (2) the Klg08 core located $6 \mathrm{~km}$ west, (3) the MAR97-02 (Hiscott et al., 2002) located $6.6 \mathrm{~km}$ north, and 4) the MD2432 located 6.7 $\mathrm{km}$ west (Fig. 1). The $110 \mathrm{~cm}$-long C8 core is too short to sample the deep thick turbidites; nevertheless, there is still a tie between the cores (Fig. S5 in the appendices). The comparison between $\mathrm{Klg} 05$ and $\mathrm{Klg} 08$ is not straightforward because of the highly compressed sedimentary record of Klg08 (Fig. S1 and S5 in appendices), but there is still a clear correspondence between event $4(56 \mathrm{~cm})$ in $\mathrm{Klg} 08$ and event 4 $(100 \mathrm{~cm})$ in $\mathrm{Klg} 05$ and between event $2(41 \mathrm{~cm})$ in $\mathrm{Klg} 08$ and event $2(48 \mathrm{~cm})$ in $\mathrm{Klg} 05$ (Fig. S5). At greater depth, the two main amalgamated turbidites around $70 \mathrm{~cm}$ depth in the core $\mathrm{Klg} 08$ correspond to the two largest turbidites (events 5 and $6)$ in Klg05. They show multiple pulses and erosional cutouts that suggest seismic triggering (Nakajima and Kanai, 2000; Shiki et al., 2000). Due to the lack of high resolution data, the comparison with MAR97-02 core (Hiscott and Aksu, 2002) is difficult. Nonetheless, this core, located $6.5 \mathrm{~km}$ to the north (Fig. 1), presents two coarser intervals at $70-110 \mathrm{~cm}$ and $140-185 \mathrm{~cm}$ depths that could correspond to the two large events e 5 and e 6 documented in Klg05 (Fig. S5 in the appendices). In addition, radiocarbon age datings are identical for the e 5 turbidite and for the coarser layer at 70$110 \mathrm{~cm}$ in the MAR97-02. Finally, the MD2432 core can be correlated to the $\mathrm{Klg} 05$ core based on the $\chi$ measurement. Density data also indicate turbiditic events that would correspond to events 3 to 6 in $\mathrm{Klg} 05$.

In the Western High, fine-grained turbidites recorded in cores $\mathrm{Klg} 06$ and $\mathrm{Klg} 07,15 \mathrm{~km}$ apart, can be easily related, because they have similar geochemical profiles (Fig. 8). In both cores, almost a one-to-one correspondence between turbidites is recorded. The two largest turbidites(e5 and e8e7 in $\mathrm{Klg} 06$ and $\mathrm{Klg} \lg$ ) are correlative and are marked by a distinctive strong terrigenous signature in sand, $\mathrm{Zr}$ and $\chi$ (Figs. 6 and S5). Silty turbidites in the Western High are dissimilar to the slump-induced turbidites present in the Tekirdağ and Central Basins, but they can have a common seismic origin. Indeed, $M>7$ earthquakes on the Tekirdağ Segment can trigger sandy turbidity currents in the basin and a muddy suspension clouds, which would deposit a very 
fine-grained distal turbidite layer in the Western High (Inouchi et al., 1996; Shiki et al., 2000).

So our final test is to look if sandy turbidites in the Tekirdağ Basin are synchronous with silty turbidites in the Western High (Fig. 10). The XRF correlation implies that the two largest turbidites(e5 and e6 in Klg05) correspond to the distinctive distal turbidites (e5 and e8-e7 in $\mathrm{Klg} 06$ ) and to $\mathrm{Klg} 07$ on the western high, marked by sand, $\mathrm{Zr}, \chi$ peaks. Furthermore, a similar number of turbidites are identified in cores above the time horizon (underlined in red in Fig. 10). Both observations suggest synchronicity of the turbidites in Tekirdağ and in the Western High. The suspension cloud responsible for the fine-grained turbidites must be at least $400 \mathrm{~m}$ thick, as the $\mathrm{Klg} 06$ site is about $400 \mathrm{~m}$ higher than the $\mathrm{Klg} 05$ site. Shiki et al. (2000) state that the plumes associated with earthquake-triggered turbidites are higher and thicker than the usual suspension clouds derived from canyon flow turbidity currents. Furthermore, McHugh et al. (2011) detected an unusual $600 \mathrm{~m}$-thick sediment plume still present almost 2 months after the $M=7.0$ Haiti earthquake. The occurrence of distal turbidites and their correlation with basinal proximal turbidites suggest that both types of turbidites were uniquely generated by earthquake shaking in the Tekirdağ Basin and not by some other natural phenomenon.

In the Central Basin, the $\mathrm{Klg} 02$ core is compared to core C4 (McHugh et al., 2006) and to core MD2429 (Beck et al., 2007). The two largest turbidites (e3 and e4) recorded in $\mathrm{Klg} 02$ were documented at the same depth in the core $\mathrm{C} 4$ of McHugh et al. (2006) (Fig. 1). Additionally, two deeper organic rich layers in $\mathrm{C} 4$ can be correlated with the e6 and e7 events of $\mathrm{Klg} 02$ (Fig. S5). In the nearby core MD2429, the magnetic susceptibility record of the first 6 metres (Beck et al., 2007) is identical to the magnetic susceptibility data of the $\mathrm{Klg} 02$ core, with two peaks framing low values (Fig. S5). These two peaks correspond to the two main sandy layers forming the base of events e 3 and e 4 . The relative low values match the main body of the second homogenite (Fig. 5). The density data of MD2429 core allow identifying other major turbidites in the cores, which correspond to events 5, 6 and 7 in Klg05. Turbidites in the Central Basin have thus significant lateral extension. We infer that they also have a seismic trigger.

\section{Paleoseismological implications}

The sedimentary cores studied provide a paleoseismological record of the Tekirdag fault ruptures. The 1912 Mürefte earthquake (event 1) was recorded in the Tekirdağ Basin and in the Western High, as well as in Central Basin where it has a faint expression. Considering the $14 \mathrm{C}$ age of $2185 \mathrm{yr} \mathrm{BP}$ below event 6 in $\mathrm{Klg} 05$ with the reservoir correction of 340$460 \mathrm{yr}$ proposed by McHugh et al. (2006), the mean recurrence time of events along the Tekirdag fault would be about $300 \mathrm{yr}$. Combining all radiocarbon age datings ob- tained in cores from the Tekirdağ Basin and an average reservoir correction of $450 \mathrm{yr}$, we can propose the following possible match between sedimentary events and historical earthquakes (Ambraseys, 2002): events 2 to 5 could correspond, respectively, to events occurring in 1766,1354 or 1343 , 1063, 557 or 437 . The obtained paleoseismological record might not be complete. The triggering of seismo-turbidites also depends on the availability and volume of unstable sediments that accumulate on the basin slopes.

The inner Central Basin ( $\mathrm{Klg} 02)$ located between the Tekirdağ and the Central faults (Fig. 1) can also record masswasting events synchronous with the Tekirdağ Basin. The first example is the 1912 disturbances triggered by the rupture of the Tekirdağ fault. Another example is the top turbidite in the Central Basin (event 3-Klg02), which seems synchronous with the shallowest turbidite in the Tekirdag Basin (event 5-Klg05; Figs. 8 and 10). The latter implies massive slope failures, both in Tekirdağ and Central Basins. It might have been triggered by the Tekirdağ fault rupture alone, but was most probably triggered by the quasisynchronous rupture of the Tekirdağ and Central faults. Such a rupture scenario may have happened during the $M=7.1$ May 1766 and $M=7.4$ August 1766 earthquake sequence, as modelled in Pondard et al. (2007).

Another noticeable paleoseismological result is the relatively low number of turbiditic events recorded in the Central Basin, which could record earthquakes rupturing in the Tekirdağ and Central Segments. It might be a side effect, as the $\mathrm{Klg} 02$ core is situated $14 \mathrm{~km}$ away from the basin slopes and only large mass wasting events can be recorded. In addition, even if sediment supply on the shelf and slope of the Central Basin is similar to the Tekirdağ Basin, there might not be enough sediments available to trigger turbiditic mass flow in the inner basin each time there is a $M>7$ earthquake on the Central or Tekirdağ faults. An other possible explanation could be frequent ruptures of the Central and Tekirdağ Segments in sequence or as a single on-going rupture. In these cases, we would have indistinguishable coeval turbiditic deposits in both basins. The last possibility would be a less frequent earthquake rupture of the Central Segment that would be related to partial creep along that specific segment. A partial creep would mean a lower recurrence rate and maximum magnitude on the Central Segment than on the other NAF segments. More sedimentary records from the Central Basin are needed to resolve that key question, which have fundamental consequences on earthquake recurrence rate and earthquake magnitude.

\section{Conclusions}

The combination of X-ray imagery, XRF scanning and highresolution granulometric measurements performed on five cores has documented the cyclic occurrence of instantaneous sedimentary events deposited in the Marmara Sea as well as 
global sedimentation changes that can be used to relate the different records. Radiocarbon age dating suggests that about eight major turbiditic events occurred in the Tekirdağ Basin and seven in the Central Basin in the last $2500 \mathrm{yr}$.

Turbiditic events appear to be reliable paleoseismological indicators of ruptures of the Tekirdag fault. This interpretation is first based on (1) specific XRF and grain size characteristics, (2) synchronicity of turbiditic events identified in different cores and (3) correlative proximal sandy turbidites in the basins with distal fine-grained turbidites in the highs. The most straightforward triggering mechanism for coeval distal and proximal events is shaking induced by earthquakes breaking the Tekirdağ Segment of the North Anatolian Fault. The relatively low number of turbidites documented in the Central Basin compared to the Tekirdağ Basin might be linked to ruptures in close sequence on the Tekirdağ and Central Segments, like in 1766 (Pondard et al., 2007) or to creeping along the Central Segment. A link is also proposed between the first observed sedimentary event and the $M=7.41912$ Mürefte earthquake. This earthquake that last activated the Tekirdağ fault left a distinct imprint in all cores. Finally, more effort must be achieved to obtain reliable age model of the sedimentary cores, which would allow a better understanding of the seismic cycle of the different NAF segments crossing the Marmara Sea.

\section{Supplementary material related to this article is available online at: \\ http://www.nat-hazards-earth-syst-sci.net/12/1235/2012/ nhess-12-1235-2012-supplement.pdf.}

Acknowledgements. We first would like to thank reviewers $\mathrm{R}$. Hiscott, N. Çağatay and the two other anonymous reviewers for their in depth comments, which improve very significantly the paper. We also thank Rolando Armijo who was the scientific director of the Marmarascarps Marine campaign in 2002 from which the studied cores were collected. We acknowledge Jean-Luc Schneider for his valuable help in core logging. We are grateful to Isabelle Billy, Joël Saint-Paul and Olivier Ther for core sampling, realisation of X-ray scanner imagery, XRF data preparation and acquisition as well as Elisabeth Michel and Elisabeth Tellier for their help on foraminifers extraction. Radiocarbon dating was supported by the CNRS-INSU Artemis program and done in the Artemis LMC14 laboratory. The program CNRS/FRS-FNRS CGRI supported granulometric data acquisition in Lige (Belgium) and the ENS, UMR8538 provides additional financial support for data acquisition. Finally, we would like to thank Christian Beck for the fruitful discussions.
Edited by: G. Lamarche

Reviewed by: R. N. Hiscott, N. Cagatay,

and two other anonymous referees

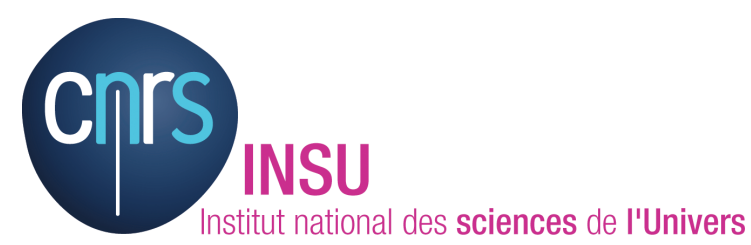

The publication of this article is financed by CNRS-INSU.

\section{References}

Abrajano, T., Aksu, A., Hiscott, R., and Mudie, P.: Aspects of carbon isotope biogeochemistry of late Quaternary sediments from the Marmara Sea and Black Sea, Mar. Geol., 190, 151-164, 2002.

Adams, J.: Paleoseismicity of the Cascadia Subduction Zone - Evidence from Turbidites off the Oregon-Washington Margin, Tectonics, 9, 1990.

Aksoy, M., Meghraoui, M., Vallée, M., and Çakır, Z.: Rupture characteristics of the AD 1912 Mürefte (Ganos) earthquake segment of the North Anatolian fault (western Turkey), Geology, 38, 991994, 2010.

Ambraseys, N.: The seismic activity of the Marmara Sea region over the last 2000 years, B. Seismolog. Soc. Am., 92, 1-18, 2002.

Armijo, R., Meyer, B., Hubert, A., and Barka, A.: Westward propagation of the North Anatolian fault into the northern Aegean: Timing and kinematics, Geology, 27, 267-270, 1999.

Armijo, R., Meyer, B., Navarro, S., King, G., and Barka, A.: Asymmetric slip partitioning in the Sea of Marmara pull-apart: a clue to propagation processes of the North Anatolian Fault?, Terra Nova, 14, 80-86, 2002.

Armijo, R., Pondard, N., Meyer, B., Uçarkuş, G., de Lepinay, B., Malavieille, J., Dominguez, S., Gutscher, M., Schmidt, S., Beck, C., Çağatay, N., Cakir, Z., Imren, C., Eriş, K., Natalin, B., Ozalaybey, S., Tolun, L., Lefevre, I., Seeber, L., Gasperini, L., Rangin, C., Emre, O., and Sarikavak, K.: Submarine fault scarps in the Sea of Marmara pull-apart (North Anatolian Fault): Implications for seismic hazard in Istanbul, Geochem. Geophys. Geosyst., 6, 1-29, 2005.

Bahr, A., Lamy, F., Arz, H., Kuhlmann, H., and Wefer, G.: Late glacial to Holocene climate and sedimentation history in the NW Black Sea, Mar. Geol., 214, 309-322, 2005.

Barka, A. A. and Kadinsky-Cade, K.: Strike-slip fault geometry in Turkey and its influence on earthquake activity, Tectonics, 7, 663-684, 1988.

Bécel, A., Laigle, M., de Voogd, B., Hirn, A., Taymaz, T., Galvé, A., Shimamura, H., Murai, Y., Lépine, J., Sapin, M., et al.: Moho, crustal architecture and deep deformation under the North Marmara Trough, from the SEISMARMARA Leg 1 offshoreonshore reflection-refraction survey, Tectonophysics, 467, 1-21, 2009.

Beck, C., de Lpinay, B. M., Schneider, J., Cremer, M., Çağatay, N., Wendenbaum, E., Boutareaud, S., Mnot, G., Schmidt, S., Weber, O., Eris, K., Armijo, R., Meyer, B., Pondard, N., Gutscher, M., the Marmacore cruise party, Turon, J., Labeyrie, L., Cortijo, E., 
Gallet, Y., Bouquerel, H., Gorur, N., Gervais, A., Castera, M., Londeix, L., de Ressguier, A., and Jaouen, A.: Late Quaternary co-seismic sedimentation in the Sea of Marmara's deep basins, Sediment. Geol., 199, 65-89, 2007.

Bertrand, S., Charlet, F., Chapron, E., Fagel, N., and De Batist, M.: Reconstruction of the Holocene seismotectonic activity of the Southern Andes from seismites recorded in Lago Icalma, Chile, 39 S, Palaeogeogr., Palaeoclimatol., Palaeoecolog., 259, 301-322, 2008.

Bottema, S. and Woldring, H.: Bronze Age and Byzantine pollen of the Kestel tin-mine (Turkey) and its possible origin: practical and experimental pollen analysis in archaeological context, Aspects of archaeological palynology: methodology and applications, AASP Contributions Series, 29, 7-15, 1994.

Butler, R.: Paleomagnetism: magnetic domains to geologic terranes, Blackwell Scientific Publications Boston, MA, ISBN086542070X, 1992.

Carton, H., Singh, S. C., Hirn, A., Bazin, S., de Voogd, B., Vigner, A., Ricolleau, A., Cetin, S., Ocakoglu, N., Karakoc, F., and Sevilgen, V.: Seismic imaging of the three-dimensional architecture of the Cinarcik Basin along the North Anatolian Fault, J. Geophys. Res.-Solid Ea., 112, B06101, 2007.

Çağatay, M., Görür, N., Algan, O., Eastoe, C., Tchapalyga, A., Ongan, D., Kuhn, T., and Kuşcu, I.: Late Glacial-Holocene palaeoceanography of the Sea of Marmara: timing of connections with the Mediterranean and the Black Seas, Mar. Geol., 167, 191-206, 2000.

Dolan, J., Christofferson, S., and Shaw, J.: Recognition of paleoearthquakes on the Puente Hills blind thrust fault, California, Science, 300, 115-118, 2003.

Eastwood, W., Roberts, N., and Lamb, H.: Palaeoecological and archaeological evidence for human occupance in southwest Turkey: the Beyşehir occupation phase, Anatolian studies, 48, 69-86, 1998.

Eris, K. K., Ryan, W. B. F., Cagatay, M. N., Sancar, U., Lericolais, G., Menot, G., and Bard, E.: The timing and evolution of the post-glacial transgression across the Sea of Marmara shelf south of Istanbul, Mar. Geol., 243, 57-76, 2007.

Folk, R.: Petrology of sedimentary rocks, Hemphill's Austin, Texas, 1968.

Fraser, J., Vanneste, K., and Hubert-Ferrari, A.: Recent behavior of the North Anatolian Fault: Insights from an integrated paleoseismological data set, J. Geophys. Res., 115, B09316, 2010.

Galli, P., Galadini, F., and Pantosti, D.: Twenty years of paleoseismology in Italy, Earth-Sci. Rev., 88, 89-117, 2008.

Goldfinger, C.: The Record of Large Turbidites and Their Relevance to the History of Earthquakes, Ann. Rev. Mar. Sci., 3, doi:10.1146/annurev-marine-120709-142852, 2011.

Goldfinger, C., Nelson, C., and Johnson, J.: Holocene earthquake records from the Cascadia subduction zone and northern San Andreas fault based on precise dating of offshore turbidites, Ann. Rev. Earth and Planet. Sci., 31, 555-577, 2003a.

Goldfinger, C., Nelson, C., Johnson, J. E., and the Shipboard Scientific party: Deep-water turbidites as Holocene earthquake proxies: the Cascadia subduction zone and Northern San Andreas Fault systems, Ann. Geophys., 46, 2003 b.

Goldfinger, C., Grijalva, K., Burgmann, R., Morey, A., Johnson, J., Nelson, C., Gutierrez-Pastor, J., Ericsson, A., Karabanov, E., Chaytor, J., Chaytor, J. D., Patton, J., and Gracia, E.: Late
Holocene rupture of the northern San Andreas fault and possible stress linkage to the Cascadia subduction zone, B. Seismol. Soc. Am., 98, 861-889, 2008.

Gorsline, D., De Diego, T., and Nava-Sanchez, E.: Seismically triggered turbidites in small margin basins: Alfonso Basin, Western Gulf of California and Santa Monica Basin, California Borderland, Sediment. Geol., 135, 21-35, 2000.

Hiscott, R. and Aksu, A.: Late Quaternary history of the Marmara Sea and Black Sea from high-resolution seismic and gravity-core studies, Mar. Geol., 190, 261-282, 2002.

Hiscott, R., Aksu, A., Yasar, D., Kaminski, M., Mudie, P., Kostylev, V., MacDonald, J., Isler, F., and Lord, A.: Deltas south of the Bosphorus Strait record persistent Black Sea outflow to the Marmara Sea since similar to $10 \mathrm{ka}$, Mar. Geol., 190, 95-118, 2002.

Hubert-Ferrari, A., Barka, A., Jacques, E., Nalbant, S., Meyer, B., Armijo, R., Tapponnier, P., and King, G.: Seismic hazard in the Marmara Sea region following the 17 August 1999 Izmit earthquake, Nature, 404, 269-273, 2000.

Inouchi, Y., Kinugasa, Y., Kumon, F., Nakano, S., Yasumatsu, S., and Shiki, T.: Turbidites as records of intense palaeoearthquakes in Lake Biwa, Japan, Sediment. Geol., 104, 117-125, 1996.

Kazanci, N., Leroy, S., Ileri, O., Emre, O., Kibar, M., and Oncel, S.: Late Holocene erosion in NW Anatolia from sediments of Lake Manyas, Lake Ulubat and the southern shelf of the Marmara Sea, Turkey, Catena, 57, 277-308, 2004.

Klinger, Y., Etchebes, M., Tapponnier, P., and Narteau, C.: Characteristic slip for five great earthquakes along the Fuyun fault in China, Nat. Geosci., 4, 389-392, 2011.

Kondo, H., Nakata, T., Akhtar, S., Wesnousky, S., Sugito, N., Kaneda, H., Tsutsumi, H., Khan, A., Khattak, W., and Kausar, A.: Long recurrence interval of faulting beyond the 2005 Kashmir earthquake around the northwestern margin of the IndoAsian collision zone, Geology, 36, 731-734, 2008.

Le Pichon, X., Sengr, A., Demirbag, E., Rangin, C., Imren, C., Armijo, R., Grr, N., Çagatay, N., Mercier de Lepinay, B., Meyer, B., SaatçIlar, R., and Tok, B.: The active Main Marmara Fault, Earth Planet. Sci. Lett., 192, 595-616, 2001.

Londeix, L., Herreyre, Y., Turon, J., and Fletcher, W.: Last Glacial to Holocene hydrology of the Marmara Sea inferred from a dinoflagellate cyst record, Rev. Palaeobot. Palynol., 158, 52-71, 2009.

Major, C., Ryan, W., Lericolais, G., and Hajdas, I.: Constraints on Black Sea outflow to the Sea of Marmara during the last glacialinterglacial transition, Mar. Geol., 190, 19-34, 2002.

Masson, D., Arzola, R., Wynn, J., Hunt, E., and P., W.: Seismic triggering of landslides and turbidity currents offshore Portugal, Geochem. Geophys. Geosyst., 2011.

McClusky, S., Reilinger, R., Mahmoud, S., Ben Sari, D., and Tealeb, A.: GPS constraints on Africa (Nubia) and Arabia plate motions, Geophys. J. Int., 155, 126-138, 2003.

McHugh, C., Seeber, L., Braudy, N., Cormier, M., Davis, M., Diebold, J., Dieudonne, N., Douilly, R., Gulick, S., Hornbach, M., et al.: Offshore sedimentary effects of the 12 January 2010 Haiti earthquake, Geology, 39, 723-726, 2011.

McHugh, C. M. G., Seeber, L., Cormier, M.-H., Dutton, J., Cagatay, N., Polonia, A., Ryan, W. B. F., and Gorur, N.: Submarine earthquake geology along the North Anatolia Fault in the Marmara Sea, Turkey: A model for transform basin sedimentation, Earth Planet. Sci. Lett., 248, 661-684, 2006. 
Migeon, S., Weber, O., Faugeres, J., and Saint-Paul, J.: SCOPIX: a new X-ray imaging system for core analysis, Geo-Mar. Lett., 18, 251-255, 1999.

Mudie, P., Rochon, A., and Aksu, A.: Pollen stratigraphy of Late Quaternary cores from Marmara Sea: land-sea correlation and paleoclimatic history, Mar. Geol., 190, 233-260, 2002.

Muller, J. and Aydin, A.: Using mechanical modeling to constrain fault geometries proposed for the northern Marmara Sea, J. Geophys. Res., 110, B03407, doi:10.1029/2004JB003226, 2005.

Nakajima, T. and Kanai, Y.: Sedimentary features of seismoturbidites triggered by the 1983 and older historical earthquakes in the eastern margin of the Japan Sea, Sediment. Geol., 135, 1-19, 2000.

Örgülü, G.: Seismicity and source parameters for small-scale earthquakes along the splays of the North Anatolian Fault (NAF) in the Marmara Sea, Geophys. J. Int., 184, 385-404, 2011.

Palike, H., Shackleton, N., and Rohl, U.: Astronomical forcing in Late Eocene marine sediments, Earth Planet. Sci. Lett., 193, 589-602, 2001.

Pettijohn, F., Potter, P., and Siever, R.: Sand and sandstone, Springer, 1987.

Pondard, N.: Le pull-apart de la Mer de Marmara (Faille Nord Anatolienne): evolution morphologique et tectonique, interactions entre failles, et a l'a sismique de la region d'Istanbul, Ph.D. thesis, Institut de Physique du Globe de Paris, 2006.

Pondard, N., Armijo, R., King, G. C. P., Meyer, B., and Flerit, F.: Fault interactions in the Sea of Marmara pull-apart (North Anatolian Fault): earthquake clustering and propagating earthquake sequences, Geophys. J. Int., 171, 1185-1197, 2007.

Reilinger, R., McClusky, S., Vernant, P., Lawrence, S., Ergintav, S., Cakmak, R., Ozener, H., Kadirov, F., Guliev, I., Stepanyan, R., et al.: GPS constraints on continental deformation in the Africa-Arabia-Eurasia continental collision zone and implications for the dynamics of plate interactions, J. Geophys. Res., 111, B05411, doi:10.1029/2005JB004051, 2006.

Robbins, J.: Geochemical and geophysical applications of radioactive lead, The biogeochemistry of lead in the environment, 1, 285-337, 1978.

Rockwell, T., Ragona, D., Seitz, G., Langridge, R., Aksoy, M., Uçarkuş, G., Ferry, M., Meltzner, A., Klinger, Y., Meghraoui, M., et al.: Palaeoseismology of the North Anatolian Fault near the Marmara Sea: implications for fault segmentation and seismic hazard, Geological Society, London, Special Publications, 316, 31-54, 2009.
Sarı, E. and Çağatay, M.: Turbidites and their association with past earthquakes in the deep Çınarcık Basin of the Marmara Sea, GeoMar. Lett., 26, 69-76, 2006.

Schmidt, S., Howa, H., Mouret, A., Lombard, F., Anschutz, P., and Labeyrie, L.: Particle fluxes and recent sediment accumulation on the Aquitanian margin of Bay of Biscay, Cont. Shelf Res., 29, 1044-1052, 2009.

Seeber, L., Cormier, M., McHugh, C., Emre, O., Polonia, A., and Sorlien, C.: Rapid subsidence and sedimentation from oblique slip near a bend on the North Anatolian transform fault in the Marmara Sea, Turkey, Geology, 34, 933-936, 2006.

Seeber, L., Emre, O., Cormier, M., Sorlien, C., McHugh, C., Polonia, A., Ozer, N., and Çağatay, N.: Uplift and subsidence from oblique slip: the Ganos-Marmara bend of the North Anatolian Transform, Western Turkey, Tectonophysics, 391, 2004.

Sengör, A., Tüysüz, O., Imren, C., Sakinç, M., Eyidogan, H., Görür, N., Le Pichon, X., and Rangin, C.: The North Anatolian fault: A new look, Annu. Rev. Earth Planet. Sci., 33, 37-112, 2005.

Shiki, T., Kumon, F., Inouchi, Y., Kontani, Y., Sakamoto, T., Tateishi, M., Matsubara, H., and Fukuyama, K.: Sedimentary features of the seismo-turbidites, Lake Biwa, Japan, Sediment. Geol., 135, 37-50, 2000.

Sperazza, M., Moore, J., and Hendrix, M.: High-resolution particle size analysis of naturally occurring very fine-grained sediment through laser diffractometry, J. Sediment. Res., 74, 736743, 2004.

Tauxe, L.: Essentials of Paleomagnetism, University of California Press, 2010.

Uçarkuş, G.: Active faulting and earthquake scarps along the North Anatolian Fault in the Seo of Marmara., Ph.D. thesis, Istanbul Technical University, 2010.

Van Zeist, W., Woldring, H., and Stapert, D.: Late Quaternary vegetation and climate of southwestern Turkey, Palaeohistoria, 17, 53-143, 1975.

Vidal, L., Menot, G., Joly, C., Bruneton, H., Rostek, F., Çağatay, M. N., Major, C., and Bard, E.: Hydrology in the Sea of Marmara during the last $23 \mathrm{ka}$ : Implications for timing of Black Sea connections and sapropel deposition, Paleoceanography, 25, doi:10.1029/2009PA001735, 2010.

Vlag, P. A., Kruiver, P. P., and Dekkers, M. J.: Evaluating climate change by multivariate statistical techniques on magnetic and chemical properties of marine sediments (Azores region), Palaeogeography, Palaeoclimatology, Palaeoecology, 212, 2344, 2004.

Weldon, R., Scharer, K., Fumal, T., and Biasi, G.: Wrightwood and the earthquake cycle: what a long recurrence record tells us about how faults work, GSA TODAY, 14, 4-10, 2004. 